NBER WORKING PAPER SERIES

\title{
WHAT DOES THE PUBLIC KNOW ABOUT ECONOMIC POLICY, AND HOW DOES IT KNOW IT?
}

\author{
Alan S. Blinder \\ Alan B. Krueger \\ Working Paper 10787 \\ http://www.nber.org/papers/w10787
NATIONAL BUREAU OF ECONOMIC RESEARCH
1050 Massachusetts Avenue
Cambridge, MA 02138
September 2004

\begin{abstract}
We are indebted to Ed Freeland, Jesse Thomas, Marc Weiner and the staff at the Princeton Survey Research Center for help conducting the survey used in this paper, to Princeton's Center for Economic Policy Studies for research support, to Jane Garrison, Courtney Stoddard, and Kathleen Hurley for expert assistance, and to members of the Brookings Panel for helpful suggestions. The views expressed herein are those of the author(s) and not necessarily those of the National Bureau of Economic Research.

(O2004 by Alan S. Blinder and Alan B. Krueger. All rights reserved. Short sections of text, not to exceed two paragraphs, may be quoted without explicit permission provided that full credit, including $\odot$ notice, is given to the source.
\end{abstract}


What Does the Public Know about Economic Policy, and How Does It Know It?

Alan S. Blinder and Alan B. Krueger

NBER Working Paper No. 10787

September 2004

JEL No. D70, E60

\begin{abstract}
$\underline{\text { ABSTRACT }}$
Public opinion influences politicians, and therefore influences public policy decisions. What are the roles of self-interest, knowledge, and ideology in public opinion formation? And how do people learn about economic issues? Using a new, specially-designed survey, we find that most respondents express a strong desire to be well informed on economic policy issues, and that television is their dominant source of information. On a variety of major policy issues (e.g., taxes, social security, health insurance), ideology is the most important determinant of public opinion, while measures of self-interest are the least important. Knowledge about the economy ranks somewhere in between.
\end{abstract}
Alan S. Blinder
Department of Economics
Princeton University
Princeton, NJ 08544-1021
and NBER
blinder@princeton.edu
Alan B. Krueger
Woodrow Wilson School
Princeton University
Princeton, NJ 08544
and NBER
akrueger@princeton.edu 
A long tradition in economic theory models economic policy decisions as solutions to optimization problems solved by rational and well-informed agents: ${ }^{1}$ A single policymaker minimizes a loss function subject to some constraints. Another body of literature models policy decisions as if they were made by well-informed voters in elections of some sort. ${ }^{2}$

As everyone knows, each of these approaches is allegorical in some respects- two of which are germane to this paper. First, apart from votes on school budgets and on some bond issues, economic (and other) policy decisions are rarely taken by direct democracy. We instead utilize representative democracy, in which elected politicians decide on our behalf. Second, in many cases, the agents making the decisions may neither be as well informed nor as rational as homo economicus. Blendon et al. (1997), for example, find large gaps between measured economic performance and the public's perception thereof. Monetary policy decisionmaking may perhaps approximate the loss-function model. Decisions there are taken by a technocrat or by a committee of technocrats, many of whom think like (or actually are) economists. ${ }^{3}$ But fiscal policy clearly is not made this way. Even if we model the President of the United States as minimizing a loss function, his recommendation is just the starting point of a long process of political horse trading. There may be 536 relevant loss functions rather than just one - and they will not all be the same. Similarly, a complex brew of politicians makes the major decisions in virtually all other areas of economic policy—such as labor laws, tax laws, environmental policy, and social insurance programs, to name just a few. ${ }^{4}$

\footnotetext{
1 "Well informed" need not connote perfectly informed. A large literature, of course, deals with imperfect information.

${ }^{2}$ Black (1948) is an early reference on the median voter model. Downs (1957) extended the model to allow for political parties. See Persson and Tabellini (2000) for a modern treatment of political economy.

${ }^{3}$ On the difference between individual and group decisionmaking in monetary policy, see Blinder and Morgan (forthcoming).

${ }^{4}$ Why this is so is an interesting question that we do not deal with here. See Blinder (1997).
} 
Of course, the fact that the voting and loss-function models are allegorical does not necessarily make them misleading, when interpreted as "as if" hypotheses. But to make a judgment on the applicability of these models of decisionmaking, it seems worth digging down deeper into the actual processes that guide policymaking. This paper takes a step in that direction.

Specifically, we take it as axiomatic that (a) the political mechanism makes almost all important economic policy decisions, and (b) the decisions of elected politicians are heavily influenced by public opinion polls. These are hardly dazzling insights. Point (a) simply states a fact; it is also central to both standard approaches to the economic theory of policymaking: loss functions and voting. Point (b) is rarely discussed by economists in their scholarly work. But its importance is apparent from the tremendous resources that politicians devote to assessing public opinion, and there is plenty of supportive evidence in political science. ${ }^{5}$

Legitimate doubts have been raised about whether the types of questions commonly asked in public opinion polls assess individuals' true preferences. ${ }^{6}$ That is not our question here because understanding the determinants of public opinion as expressed in standard polls remains important as long as these polls influence politicians' policy decisions. This point remains valid irrespective of whether people understand the issues well or are confused about them, whether they are self-interested or public-spirited, and whether they are well-informed or poorly-informed.

If we accept these points, a host of interesting questions arise, two of which are the foci of this paper. First, to what extent is mass public opinion shaped by political ideology, self-interest, and — don't laugh—economic knowledge? Second, to the extent that knowledge is relevant to opinions on issues, how do people inform themselves?

\footnotetext{
${ }^{5}$ Among the many references that could be cited, see Page and Shapiro (1983) and Monroe (1979).

${ }^{6}$ See, for example, Kahneman (1986).
} 
This paper offers many detailed answers to these and related questions, so it may be useful to begin with a broad characterization that may help the reader see the forest amidst all the trees to follow. Subject to many caveats, we find that ideology is the most consistently important determinant of public opinion on a number of major economic policy issues, and objective measures of material self-interest are the least important. ${ }^{7}$

Knowledge about the economy ranks somewhere in between-sometimes it is important, but sometimes it is not. To us, this does not paint a picture in which homo economicus is in charge.

Our evidence comes from a unique, new telephone survey of a random sample of the U.S. population over age 18. The paper is organized as follows. We begin by setting up a recursive model of the formulation of public opinion. Next, we explain the survey that we designed and implemented, including some of the specific questions. ${ }^{8}$ Two lengthy sections comprise most of the paper. The first discusses some of the more interesting tabulations and cross-tabulations of the data; these are the straight facts. The second presents estimates of our econometric model of public opinion. We conclude with some overarching, though admittedly speculative, interpretations of our findings.

\section{On The Determinants of Public Opinion}

To formulate an estimable model of how public opinion on economic policy issues is formed, we work backward. To the extent that the process is rational at the individual level, a person's position on an issue should depend on (a) her self interest, (b) her

\footnotetext{
${ }^{7}$ Our findings are consistent with Citrin and Green's (1990, pp. 16-17) survey of the political science literature, which concludes, "Taken as a group, the studies summarized above appear devastating for the claim that self-interest, defined narrowly as the pursuit of immediate material benefits, is the central motive underlying American public opinion. ... When self-interest effects did appear, they generally were weaker than the influence of alternative sources of opinions such as values, feelings of group solidarity or ideology."

${ }^{8}$ We do not include the survey instrument here because it is long (over 40 pages) and a bit hard to read owing to complexities in the skip pattern. It is available, along with additional descriptive statistics, under "Economic Issues Survey" on the website of the Princeton Survey Research Center at http://www.wws.princeton.edu/ psrc/surveys.html.
} 
ideology or "values", (c) her factual knowledge and conceptual understanding of the issue, and (d) the degree to which she bases her decision on self interest versus her perception of what is in the public interest. ${ }^{9}$ The last of these is likely the hardest to measure, even by asking people. Our basic model is:

(1) $O P_{i}=f\left(S I_{i}, I D_{i}, K_{i}, E D_{i}, X_{i}\right)+e_{1 i}$, where $\mathrm{OP}=$ opinion of person $\mathrm{i}$ at the time of the survey, $\mathrm{SI}=$ self-interest, $\mathrm{ID}=\mathrm{ideolog}$, $\mathrm{K}=$ knowledge, $\mathrm{ED}=$ education, $\mathrm{X}=\mathrm{a}$ vector of "demographic" variables such as race, sex, age, and income, and $\mathrm{e}_{1 \mathrm{i}}$ is an error term. ${ }^{10}$

Our survey elicits some information about each respondent's ideology and self interest. But we make no attempt to explain how any particular person's values and ideology were formed, nor why his or her self interest is what it is. We simply treat these variables as econometrically exogenous. (For example, one of our "self interest" variables is income. We make no attempt to explain family income.) Our main focus is on the acquisition of information, where the survey probed much more deeply.

The amount and kind of knowledge a person has on any particular economic issue ought to depend on the costs and benefits of acquiring such knowledge. Our survey was thus designed not only to measure how well-informed respondents are, but also how and where they get their information. Thus:

$$
\text { (2) } \mathrm{K}_{\mathrm{i}}=\mathrm{g}\left(\mathrm{ED}_{\mathrm{i}}, \mathrm{D}_{\mathrm{i}}, \mathrm{S}_{\mathrm{i}}, \mathrm{Q}_{\mathrm{i}}, \mathrm{X}_{\mathrm{i}}\right)+\mathrm{e}_{2 \mathrm{i}} \text {, }
$$

where $\mathrm{D}$ is a survey measure of how strongly the respondent desires to be informed about the economy and economic policy, $\mathrm{S}$ is a vector representing the sources of information that the individual uses, and Q is an indicator of the quantity or intensity of information. The specific definitions are explained in the next section.

\footnotetext{
${ }^{9}$ See Zaller (1992) for an alternative, though related, framework of how individuals acquire and transform information into responses to public opinion questions that does not start by assuming rationality.

${ }^{10}$ There might well be lags in this process, but we have no time-series information.
} 
Finally, we try to explain why people do or do not choose to inform themselves, and in what ways:

(3) $\mathrm{S}_{\mathrm{i}}=\mathrm{h}_{1}\left(E \mathrm{ED}_{\mathrm{i}}, \mathrm{D}_{\mathrm{i}}, \mathrm{SI}_{\mathrm{i}}, \mathrm{ID}_{\mathrm{i}}, \mathrm{X}_{\mathrm{i}}\right)+\mathrm{e}_{3 \mathrm{i}}$

(4) $\mathrm{Q}_{\mathrm{i}}=\mathrm{h}_{2}\left(\mathrm{ED}_{\mathrm{i}}, \mathrm{D}_{\mathrm{i}}, \mathrm{SI}_{\mathrm{i}}, \mathrm{ID}_{\mathrm{i}}, \mathrm{X}_{\mathrm{i}}\right)+\mathrm{e}_{4 \mathrm{i}}$

(5) $\mathrm{D}_{\mathrm{i}}=\mathrm{h}_{3}\left(\mathrm{ED}_{\mathrm{i}}, \mathrm{SI}_{\mathrm{i}}, \mathrm{ID}_{\mathrm{i}}, \mathrm{X}_{\mathrm{i}}\right)+\mathrm{e}_{5 \mathrm{i}}$

So, and now working forward from "causes" to "effects," our model is that people's self-interest, ideology, education, and desire to be informed combine to determine how much information they acquire - and what kinds of information (equations 3-5). This information, along with their education and desire to be informed, determines their knowledge of an issue (equation 2). And this knowledge, along with their ideology and self interest, determines their opinions (equation 1). We pay closest attention to the first three equations: how people inform themselves, the determinants of knowledge, and the determinants of mass public opinion.

\section{The Survey}

In the spring of 2003, we conducted a telephone survey of a random sample of the U.S. population over the age of 18 , using random digit dialing. ${ }^{11}$ As is typical for surveys of this type, the response rate (calculated according to the American Association of Public Opinion Research guidelines) was low_-just 26\% of working residential numbers. But, perhaps surprisingly, the available evidence does not suggest that such low response rates lead to major statistical biases. ${ }^{12}$ In any case, we completed 1,002 interviews and then weighted the responses to match the March 2002 CPS population estimates in the

\footnotetext{
${ }^{11}$ The survey was conducted by Princeton University's Survey Research Center. The interviews began on March $28^{\text {th }}$ and ended on June $3^{\text {rd }}$. In the case of "no answers," the survey protocols called for up to eight call-backs. It has been suggested to us that mentioning Princeton University might have affected the response rates. But the sample did not look exceptional in terms of education, age, or other objective attributes.

${ }^{12}$ See, for example, Keeter et al. (2000).
} 
following five respects: race, age, sex, education, and geographical region. ${ }^{13}$ All the numbers reported in this paper reflect that weighting.

The survey, which typically took 12-17 minutes to administer, began with a series of questions about economic policy issues - some of which are factual and some of which solicit the respondent's opinion. An example of the former is:

- Roughly what size (in billions of dollars) is this year's federal budget deficit?

An example of the latter is:

- Do you think the federal budget deficit ought to be reduced?

The five policy issues we dealt with are taxes, the federal budget deficit, the minimum wage, Social Security, and health insurance. Each issue involves several questions. In some cases (detailed below), the ordering of the questions was randomized. But ordering rarely mattered.

After thus giving people an idea of the sort of economic policy issues in which we were interested, the survey went on to inquire about how they become informed about such issues. The transition question to that part of the survey was:

- Next, we'd like to know how important it is to you to keep well-informed about major economic policy issues, such as the ones we have just been discussing. Would you say it is extremely important, very important, somewhat important, not very important, or not important at all? (emphasis added)

The answers to this question comprise the "desire to be informed" variable, $\mathrm{D}_{\mathrm{i}}$ in equations (3)-(5). Notice the deliberate framing of what we mean by "major economic policy issues."

That initial question about the importance of information was followed by a series of inquiries into "the sources of information you use, either to learn about economic issues or to learn the opinions of others on these issues." One prototypical example is:

\footnotetext{
${ }^{13}$ Without weighting, females, senior citizens, the college educated, and non-Hispanic whites would all have been over-represented. The weights for each observation are derived from an iterative procedure that balances the five variables. So we do not match the CPS counts exactly.
} 
- Do you watch television regularly, occasionally, or not at all to learn about economic issues?

Similar questions were asked for 10 other sources of information: radio, newspapers, magazines, books, statements by political leaders, statements by business leaders, statements by economists, statements by civic or religious leaders, discussions with friends and relatives, and the Internet (in that order). Most people presumably encounter statements by political leaders, business leaders, or economists via one of the standard media channels (e.g., television or newspapers). But, in our judgment, information from these three groups of "experts" was sufficiently different from the standard media fare (e.g., new reports) that they merited inclusion on their own.

The final section of the survey collected data on individual characteristics, including the usual demographic variables (race, age, sex, etc.), but also including less standard variables that relate to the five policy issues, such as income, whether the person reported voting in the 2000 election, whether or not the respondent was covered by health insurance, and whether the respondent's parents were alive.

\section{Some Straight Facts}

There are no well-accepted models of the phenomena we are studying, the directions of causation among the variables we have collected are not always obvious (and in some cases are clearly multi-directional), and we have a paucity of truly exogenous variables. (Race, sex, and age are the only unexceptionable ones.) So valid objections can surely be raised against any identifying assumptions we might propose in formulating a regression model — such as the recursive structure we impose. Undaunted, we will nonetheless do so when we estimate econometric models later. But before jumping into such controversial waters, we first provide an exploratory analysis of the data without imposing any structure on them. 


\section{The demand for economic information}

We begin with the desire to be informed, the variable D in the model. Almost $24 \%$ of respondents said it was "extremely important" "to keep well-informed about major economic policy issues," and just over 50\% said it was "very important." Another $23.5 \%$ characterized keeping well informed as "somewhat important," leaving under $3 \%$ of the sample in the "not very important" or "not important at all" categories. Frankly, we were surprised — and pleased — by the strength of the expressed desire to be informed. ${ }^{14}$

When we look across subgroups of the population, the answers to this question do not vary significantly (at the 5\% level) by race, sex, education, or income. But older respondents expressed a slightly stronger desire to be well-informed. We also divided the sample into those who were working at the time of the survey ( $56 \%$ of the sample) and those who were not. The working population turned out to have a slightly weaker desire to be informed, compared to the heterogeneous non-working group, which includes the unemployed, retirees, homemakers, and students.

In a survey that inquires about information relevant to economic policy issues, we expected to find many systematic differences by political ideology. So respondents were asked to classify themselves as liberal (15\% of our sample), conservative (29\%), moderate (19\%), other (4\%), or "haven't thought much about it" (33\%). As a shorthand, we will refer to the latter group as the "non-politicals". Notice that it is the largest group. Using all five categories in a $\chi^{2}$ test of independence, we find little evidence of differences in the desire to be informed by ideology $\left(\chi^{2}=28.6, \mathrm{p}=.133\right)$.

\footnotetext{
${ }^{14}$ The interviewers' script began: "Hi. My name is ___ _ and I'm calling from Princeton University to conduct a 15-minute survey about economics and access to economic information." Given this preface, perhaps respondents believed they should express a desire to be informed. On the other hand, the question about desire to be informed came after a series of daunting questions on policy issues, which may have deflated some respondents' beliefs about how well informed they actually were.
} 
However, we do find rather strong differences by a variable that might be called "political engagement" (rather than partisanship). Specifically, we asked respondents whether they voted in the 2000 presidential election. The answers to this question do not represent actual voting behavior accurately, since $68 \%$ of our respondents claim to have voted whereas the national data show that only $51 \%$ actually did. ${ }^{15}$ They may instead indicate which respondents believe they should have voted (as well as those who actually voted). In any case, the self-described "voters" were considerably and significantly $\left(\chi^{2}=\right.$ $26.0, p=.001)$ more interested in keeping informed than were the non-voters. Fully $78 \%$ of "voters" said keeping well-informed was either extremely or very important to them, versus only $66 \%$ of nonvoters. This strong correlation supports our view that selfprofessed voting is an indicator of political engagement. As further support of the notion that the so-called "non-politicals" are disengaged, we note that only $47 \%$ of them reported voting in 2000 - versus $79 \%$ of everyone else.

Multiple regression estimates of equation (5) above were not very informative, however, and hence are not reported. We began by estimating an ordered probit model using the three regressors suggested by the simple correlations: age, working status, and whether the individual claims to have voted. Only the last of these was significant. We then experimented with a variety of demographic, ideology, and self-interest variables, as per equation (5), but found hardly any other significant regressors. In a word, our ability to predict a person's desire to be informed based on measurable variables is negligible.

The next survey question asked each respondent who said that being informed was at least "somewhat important" to tell us "the main reasons why you wish to be wellinformed," listing as choices the five reasons shown in Table 1. Just over half of our respondents gave the last response, which might be called "the civics class answer." But,

\footnotetext{
${ }^{15}$ See the Federal Election Commission data at www.fec.gov/pages/2000turnout/reg\&to00.htm. Our finding of over reporting of voting by 17 percentage points is in line with other surveys (see, for example, Erikson).
} 
perhaps inconsistently, only $22 \%$ offered politics or voting as a reason. Slightly more than half mentioned the relevance of economic issues to their personal finances. But, in a big surprise to us, under $4 \%$ specifically mentioned the stock market as a reason for wanting to keep informed. Do these answers vary by personal characteristics? The only general answer is: somewhat. More specifically:

Demographics: Differences by age, sex, and race were generally minor. The only notable ones were that older people were slightly more likely to list the last response shown in Table 1 than younger people (59\% versus $51 \%$; $=.043),{ }^{16}$ and that men were more likely than women to list the idea that being informed might be politically important or affect their vote (by $26 \%$ versus $19 \% ; p=.010$ ). Because racial differences are so ubiquitous in cross-section work, we were surprised to find no significant racial differences in the professed reasons for desiring to be well-informed.

Economic status: Differences by education, employment status, and income were more notable. For example, college-educated people were substantially more likely than others to list three of the five reasons for wanting to be informed: the relevance of economic information for politics or their vote (by $35 \%$ versus $17 \%$; $p=.000$ ), the relevance to their business or profession (by $10 \%$ versus $6 \% ; p=.008$ ), and personal finances (by $60 \%$ versus $51 \%$; $\mathrm{p}=.018$ ). Not surprisingly, employed people were much more likely $(10 \%$ versus $3 \%, \mathrm{p}=.000)$ to mention their job or profession as a reason for wanting to keep informed about the economy. And differences by income class were pervasive. ${ }^{17}$ Compared to lower-income people, higher-income people were more likely to mention their personal finances $(59 \%$ versus $48 \%, \mathrm{p}=.005)$, their business or profession ( $10 \%$ versus $4 \%, \mathrm{p}=.001)$, and the relevance to politics and voting $(26 \%$

\footnotetext{
${ }^{16}$ Since the mean and median ages in our sample are both approximately 45 , we divided our sample into "younger" and "older" subsamples at that age.

${ }^{17}$ For these $\chi^{2}$ tests, we divided the sample at the $\$ 40,000$ mark, which is close to the median; $45 \%$ of the sample reported a family income of $\$ 40,000$ or less. The next income bracket was $\$ 40,000-\$ 60,000$.
} 
versus $18 \%, p=.025)$, but less likely to mention their general desire to be well-informed $(50 \%$ versus $62 \%, p=.004)$.

Political involvement: Respondents of different political ideologies differed only in how often they mentioned politics or voting as a reason for keeping informed. However, this difference appears to be more a matter of detachment than ideology: Non-politicals were substantially less likely (8\%) to cite politics than either liberals $(27 \%)$, conservatives $(28 \%)$, or moderates $(31 \%)$. Across these four categories, the $\chi^{2}$ test of independence is highly significant $\left(\chi^{2}=52.4\right)$. Consistent with this, self-described voters were much more likely than non-voters to cite politics or voting as a reason to keep informed $(27 \%$ versus $12 \%, \mathrm{p}=.000)$.

\section{The sources of economic information}

The lengthiest part of the questionnaire inquired about the sources of information people use to inform themselves. As mentioned in the previous section, we asked specifically about the frequency of use of each of eleven possible sources of information about economic issues, and we coded the responses as either "regularly or often," “occasionally," or "rarely or never." Table 2 ranks the eleven sources from the most frequently used (television) to the least (books). It is hardly surprising that television is the most popular source of information — by a substantial margin.

We followed this question by asking respondents whether they "learn more about economics from the networks, from cable, or about the same from both," with the following results:

$\begin{array}{ll}\text { Network stations } & 17 \% \\ \text { Cable stations } & 28 \% \\ \text { About the same } & 44 \%\end{array}$

Although it reaches many fewer viewers, cable has a noticeable edge. 
It is also not surprising that newspapers rank second as a source of economic information. But we would not have predicted that more people get their economic information from local newspapers (54\%) than from any of the six national newspapers $(23 \%)$ listed in the survey or from any other "big city" newspaper $(19 \%) .{ }^{18}$ Remember, we pre-conditioned this response by first asking questions about national issues like the federal budget deficit and Social Security, not about the local school budget or personal finance. Finally, we inquired about which sections of the newspaper people "turn to, to learn about the economy or economic policy." The business/financial (43\%) and national news $(39 \%)$ sections received the most votes, while the editorial page (including op-eds) lagged way behind (9\%).

Once we peer below first and second place in Table 2, our priors on the rankings were pretty diffuse. "Discussions with friends and relatives" ranked third, narrowly edging out "statements by political leaders." We were somewhat surprised to learn that radio is used so little, and we were quite surprised by the minimal use of magazines. (This includes the mass-circulation magazines like Time and Newsweek.) But we were gratified to find "statements by economists" ranking right in the middle of the eleven sources, ${ }^{19}$ beating out the Internet, business leaders, civic or religious leaders, magazines, and books. ${ }^{20}$ Finally, it is worth noting that Table 2 probably underestimates the dominance of television since many people probably hear the views of political leaders, economists, and business leaders on television. ${ }^{21}$

We concluded the section on sources of information by reading back to each respondent the lists of sources he or she had reported using "regularly or often" and then

\footnotetext{
18 The six national publications were: the New York Times, Washington Post, Wall Street Journal, USA Today, Financial Times, and Investors' Business Daily. Examples of "other big city newspapers" were the Boston Globe and the San Francisco Chronicle.

${ }^{19}$ About one-sixth of the people who said they learn about the economy from economists "regularly" or "occasionally" specifically mentioned Alan Greenspan as the economist. We did not prompt that response.

${ }^{20}$ Where the rankings of the distributions shown in Table 2 were ambiguous, we broke the tie by assigning point scores as follows: regularly $=3$, occasionally $=2$, rarely $=1$.

${ }^{21}$ Some of this information also comes from radio, magazines, the Internet, and newspapers, of course.
} 
asking: "which... is your most important source of information on economics or economic policy." By this alternative criterion, the rankings of sources are rather different (see Table 3). Television and newspapers still rank first and second, respectively; but the margin for TV is now enormous. After that, the rankings in Tables 3 differ noticeably from those in Table 2, with, e.g., the Internet ranking much higher and, alas, economists ranking much lower. Overall, the rank correlation between Tables 2 and 3 is 0.76 .

In a word, television tops the list of how Americans get their economic information; everything else lags well behind. But not all people are alike. As we did with the reasons for desiring to be informed, we next looked for statistically significant (at the $5 \%$ level) differences in the frequency of use of the sources of information by demographics, economic status, and political engagement. There were many, so we summarize them briefly.

Demographics: $\chi^{2}$ tests show that older respondents made significantly greater use of most, but not all, sources of information. But younger respondents used radio and the Internet more. Men reported making greater use of radio, business leaders, economists, and the Internet, while women reported greater use of civic or religious leaders. Racial differences were less common. Whites used TV more, while nonwhites used magazines, books, and civic and religious leaders more.

Economic status: We found significant differences in the usage of six of the eleven sources (radio, newspapers, magazines, business leaders, economists, and the Internet) by education. In each case, college-educated people reported using the information source more. Similarly, higher-income respondents made significantly greater use of six sources: newspapers, radio, the Internet, political leaders, business leaders, and economists. In only one case did lower-income people use an information source more intensely: 
statements by civic or religious leaders. Differences by employment status were less common; non-employed people reported using books and the Internet more.

Political involvement: Although we found significant differences in information use by "ideology" in eight of the eleven cases, the differences did not typically cut across liberal/conservative lines. As a broad generalization, it was the non-political group that stood apart from the rest by making less use of information. Similarly, self-described voters were more likely to use eight of the eleven sources.

Although the types of media used by liberals and conservatives are similar, we do find ideological differences in the particular newspapers that individuals choose to read. Table 4 shows the proportion of people who obtain information about the economy from each of the major newspapers, classified by self-identified ideological affiliation. ${ }^{22}$ Liberals are a stunning eight times more likely than conservatives to read The New York Times, and conservatives are twice as likely as liberals to read The Wall Street Journal. But we do not find any ideological divide in the use of cable stations versus network $\mathrm{TV}^{23}$

Finally, for use as empirical counterparts to the theoretical variable Q (quantity of information) in equation (2), we constructed two measures of how intensively each respondent used the various sources of information. Remember, each person was asked how often he or she used each source. Let $\mathrm{s}_{1}, \mathrm{~s}_{2}, \mathrm{~s}_{3}$ be, respectively, the number of sources used "regularly or often", "occasionally," or "rarely or never"; and let the total number of sources, $s$, equal $s_{1}+s_{2}+s_{3}$. (Note that $s$ can be less than eleven because of item nonresponse.) Then define $\mathrm{Q}_{\mathrm{H}}$ (“quantity high”) and $\mathrm{Q}_{\mathrm{L}}$ (“quantity low”) respectively as $\mathrm{s}_{1} / \mathrm{s}$ and $\mathrm{s}_{3} / \mathrm{s} . \mathrm{Q}_{\mathrm{H}}$ and $\mathrm{Q}_{\mathrm{L}}$ thus measure intensity of information use and lack of intensity,

\footnotetext{
${ }^{22}$ These numbers need not, and do not, mirror published circulation figures. For example, almost as many people report learning about the economy from The New York Times (8.2\%) as from The Wall Street Journal (8.7\%), even though the Journal's (weekday) circulation is almost double that of the Times.

${ }^{23}$ See Hamilton (2004) for an analysis of trends in "media bias" and the impact of competition on partisan news reporting.
} 
respectively. Because not all sources of information convey equal information, our measures are undoubtedly crude proxies; but they are probably still correlated with the extent to which individuals access information about the economy.

The distributions of these two variables in the overall sample are shown in Table 5. Not surprisingly, the frequency distribution of $\mathrm{Q}_{\mathrm{H}}$ (high intensity) is piled up at the low end: Fewer than $15 \%$ of respondents have a $\mathrm{Q}_{\mathrm{H}}$ greater than 0.4 , while $32 \%$ have $\mathrm{Q}_{\mathrm{H}}$ below 0.1. Perhaps more surprisingly, the distribution of the variable $\mathrm{Q}_{\mathrm{L}}$ (low intensity) is not piled up at the high end: Under $14 \%$ of respondents have $\mathrm{Q}_{\mathrm{L}}$ above 0.7 while $73 \%$ have $\mathrm{Q}_{\mathrm{L}}$ between 0.2 and 0.7 .

Looking across personal characteristics, we found some of the empirical regularities one might expect. College-educated people, high-income people, and self-professed voters reported significantly more intensive use of information sources. Compared to either liberals, conservatives, or moderates, the non-politicals had significantly lower $\mathrm{Q}_{\mathrm{H}}$ and significantly higher $\mathrm{Q}_{\mathrm{L}}$. All these differences are significant well beyond the $0.1 \%$ level. The other personal characteristics — age, race, sex, and employment status — did not seem to matter much. ${ }^{24}$

\section{Knowledge about economic issues}

In the context of asking a series of questions about the five economic policy issues, we embedded nine "fact" questions whose purpose was to assess each respondent's knowledge. The questions inquired about:

1. the share of income that a typical American family pays in taxes

2. whether most people pay more in payroll or income taxes

3. the size of the federal budget deficit

4. the level of the federal minimum wage

5. the size of the average Social Security benefit check

6. whether they knew that President Bush had proposed partial privatization of Social Security

\footnotetext{
${ }^{24}$ There were two minor exceptions. Whites had slightly higher average values of $\mathrm{Q}_{\mathrm{L}}$ than non-whites, and the employed had lower $\mathrm{Q}_{\mathrm{L}}$ than the non-employed.
} 
7. whether they knew that the Social Security System is projected to start running deficits in about a decade

8. whether Medicare covered prescription drugs for outpatients (at the time of the survey)

9. the percentage of Americans who do not have health insurance.

We were surprised to find, as a broad generalization and with exceptions to be noted shortly, that the average responses to most of these questions were roughly correct (although the standard deviations were often huge). With one big exception - the federal budget deficit — there was also hardly any indication of skewness: Mean and median responses were close. Table 6 below compares the actual facts with the survey results. Several comments are in order.

The correct tax share is a difficult question conceptually. Most economists think first of taxes as a share of GDP, which was $28.4 \%$ in 2002 . But the denominator of this ratio (GDP) is meaningless to most people, and the numerator includes many taxes that people probably do not think of themselves as paying. ${ }^{25}$ So we posed a more user-friendly version of the question in the survey:

- About what percentage of the typical American family's income do you think goes to paying taxes-including all levels of government?

For the denominator of this ratio, we added the employee's share of the payroll tax to personal income as defined in the National Income and Product Accounts (NIPA). For the numerator, we included personal income taxes, estate and gift taxes, the employee's share of the payroll tax, almost all sales and excise taxes, and property taxes on owneroccupied housing - all from the NIPA. But we excluded corporate income taxes, the employer's share of the payroll tax, property taxes on rental housing, customs duties, and the excise tax on diesel fuel on the grounds that individuals are unlikely to think of

\footnotetext{
${ }^{25}$ Two prominent examples are the corporate income tax and the employer's share of the payroll tax. This example illustrates a general and important point about public opinion polling. Economists often want to see survey questions that make sense to them. Such questions may involve complicated concepts and numerous provisos that leave ordinary people confused. Good poll questions need to be understandable by ordinary people with limited attention spans and no training in economics.
} 
themselves as paying those taxes. The resulting tax share in calendar year 2001 was

$23.3 \%$. Thus we were left with two alternative interpretations of the mean survey

response of $31.3 \%$ : It was either a small overestimate of the tax share of GDP or a

substantial overestimate of our constructed tax share. We favor the latter interpretation.

Note also that the standard deviation across respondents was very large - more than 15

percentage points.

About $83 \%$ of tax filers with wage income pay more in payroll taxes than they do in income taxes. ${ }^{26}$ But our respondents thought the reverse was true, by a decisive margin of $52 \%$ to $35 \% .^{27}$

Estimates of the federal budget deficit — whether for fiscal year 2003 or 2004-were rising sharply while our survey was in the field. We therefore decided to count any number between $\$ 246$ billion and $\$ 310$ billion as correct; these were the official CBO estimates published on March 10, 2003 and May 9, 2003, respectively. In fact, the mean estimate in the survey (\$334 billion) was amazingly accurate, especially since privatesector estimates at the time were running well above CBO's estimates. However, the variance across respondents was truly astounding-we received estimates of the federal budget deficit as low as \$1 billion and as high as \$5 trillion. The median response-just $\$ 90$ billion - also showed that the "typical" response was far too low. ${ }^{28}$

The average (and median) estimate of the federal minimum wage was also quite accurate, especially when you consider that some respondents may have given the higher state minimum wage instead. ${ }^{29}$

\footnotetext{
${ }^{26}$ See Gale and Rohaly (2003). The 83\% figure includes both the employer and employee components of the payroll tax. If just the employee tax is used, then $53 \%$ of wage earners pay more in payroll taxes than income taxes.

${ }^{27}$ The remaining 13\% did not know or thought they were about the same. Bartels (2003, p. 19) reports results from an NPR/Kaiser Foundation/Kennedy School survey that found that people are even more inaccurate in assessing whether they themselves pay more in income or payroll taxes. To us, this suggests that many people simply do not distinguish between income and payroll taxes.

${ }^{28}$ Nonresponse was also quite high on this question-about $48 \%$, suggesting that there was even less knowledge than the reported estimates indicate.
} 
Average Social Security benefits were also estimated quite accurately in the survey, although the variance was again enormous and fully $18 \%$ of respondents were unable to answer the question. Similarly, majorities of respondents said they were aware "that President Bush has proposed that part of Social Security be replaced by personal investment accounts" and "that the Social Security system is projected to start running deficits about a decade from now." In general, public knowledge of the Social Security system seemed pretty high.

Not so for health insurance, however. A bare majority (54\%) realized that Medicare did not, at the time of the survey, cover prescription drugs "when people are not in the hospital"- despite an avalanche of recent public attention to the issue. ${ }^{30}$ And perhaps the greatest misconception in the survey was the belief that a stunning $37 \%$ "of Americans do not have any health insurance today." The actual number in 2002 was $15.2 \%$.

Each of the nine "knowledge" questions above will be used in context later, when we study public opinion on specific policy issues. But we also constructed a generic knowledge score — the variable $\mathrm{K}$ in our model — as follows. Five of the questions (numbered 1, 3, 4, 5, and 9 in the list above) have numerical answers. For each of these questions, we computed the absolute error, and then assigned each respondent a percentile rank based on accuracy, $\mathrm{P}_{\mathrm{ij}}$, where $\mathrm{i}$ indexes individuals and $\mathrm{j}$ indexes questions. We also assigned numerical scores to two qualitative questions (numbers 2 and 8 in the list above), setting the values for the various answers so that the mean score was the $50^{\text {th }}$ percentile (just like the numerical questions) and the standard deviation approximated that of a uniform distribution $(\sigma=28.9 \%)$. However, in computing our composite knowledge score, we gave only $50 \%$ weight to these two questions because it

\footnotetext{
${ }^{29}$ Some respondents explicitly said that they reported estimates of their state minimum wage. When we compute errors below, we use the state minimum wage as the true value if a respondent mentioned that he or she was reporting the state minimum wage.

${ }^{30}$ The $54-46$ split excludes the $11 \%$ of respondents who did not answer the question.
} 
was easier to guess the correct answer. We excluded the two Social Security questions that began "Are you aware that..." (numbers 6 and 7 in the list) on the grounds that the phrasing probably often "led the witness" to the correct answers. We then summed these ranks across all the (weighted) questions the respondent answered to obtain $\mathrm{K}_{\mathrm{i}}=(1 / 6) \Sigma_{\mathrm{j}}$ $\mathrm{P}_{\mathrm{ij}}$. Note that we always divide by six. ${ }^{31}$ The knowledge measure thus treats unanswered questions exactly as they would be treated on an exam: They get zero points. Strikingly, the distribution of our constructed knowledge variable across the population of respondents closely resembles a normal distribution with a mean of 42.9 and a standard deviation of 16.7; see Figure 1.

How does economic knowledge, thus measured, vary by personal characteristics, by the desire to keep informed, by the main sources of information, and by the number of information sources an individual uses?

Personal characteristics: There were no significant differences in mean knowledge score by age, and only minor differences by sex and race. Larger and more highly significant differences (all have p values below .001) emerged when we considered:

- Economic status: Higher-income people outscored lower-income people on our test by 8.6 points $(0.51 \sigma)$. The scores of college-educated respondents averaged 6.3 points $(0.38 \sigma)$ higher than the scores of non-college-educated respondents. This is far smaller than the gap of $0.9 \sigma$ units recorded on the 1994 U.S. International Adult Literacy Survey; the difference is probably because our assessment is based on just seven questions, and is therefore noisy. ${ }^{32}$

- $\quad$ Political involvement: Once again, the non-political group stood out from the rest with unusually low scores (about 6-7 points lower than liberals, conservatives or

\footnotetext{
${ }^{31}$ About half the sample was not asked for their estimate of the budget deficit. For these people, we summed the (weighted) ranks and divided by five instead.

${ }^{32}$ As another point of comparison, Hansen, Heckman and Mullen (2004) find that scores on the Armed Forces Qualifying Test rise by 0.17 standard deviation for each year of schooling. The difference in years of schooling between college graduates and non-graduates is 4.5 years, so this amounts to a .77 $\sigma$ gap, or twice what we find for our test.
} 
moderates), and self-reported voters scored 8.5 points higher, on average, than nonvoters. $^{33}$

Differences by desire to keep informed: It seems almost axiomatic that individuals who deem it more important to keep informed should actually be better informed. But the knowledge scores do not really bear this out, except for the lowest category (see Table 7). While the ordering is correct, the null hypothesis that all four means scores are equal cannot be rejected at the $5 \%$ level $(\mathrm{p}=.07)$.

Differences by major source of information: Table 8 shows that the small number of people who said that magazines are their primary source of information on economic issues (readers of The Economist?) were the most knowledgeable group (mean K score $=52.7$ ). The even smaller number of people whose most important source of information was statements by economists ranked second (mean $\mathrm{K}=50.3$ ). The least knowledgeable people, by far, were the small group that relies most on statements by civic and religious leaders (mean $\mathrm{K}=35.0$ ). Those whose most important source was television-a plurality of the sample_-had a relatively low mean K score of 41.1.

Differences by quantity of information: Table 9 displays a positive, but by no means high correlation between the knowledge score and the number of different sources that the respondent reports using regularly. Thus, more information does improve knowledge, albeit very imperfectly. The null hypothesis that all the $\mathrm{K}$ scores are equal in Table 9 is rejected at beyond the $0.1 \%$ level, but the relationship is not monotonic.

Direction of Errors: Our test scores are based on absolute errors, without regard to sign. But it has been suggested that conservatives and liberals may make systematically different errors because the two groups seek out and utilize different sources of information in order to see their beliefs confirmed. ${ }^{34}$ Although conservatives and liberals

33 This result is consistent with Palfrey and Poole's (1987) results for political knowledge.

${ }^{34}$ See Mullainathan and Shleifer (2003). 
had similar average percentile scores on the knowledge test, we did find some differences in the direction of their errors.

On average, conservatives thought that the federal budget deficit was much larger (\$333 billion vs. $\$ 177$ billion), that Social Security benefits were a bit more generous (\$873 vs. \$766 per month), and that a lower share of the U.S. population lacked health insurance (32\% vs. $40 \%$ ) - all as compared to liberals. Conservatives were also more likely than liberals to report being aware that the Social Security trust fund is projected to run a deficit in about a decade (82\% vs. $74 \%$ ) and less likely to say that Medicare already provided coverage for prescription drugs (23\% vs. 34\%). While each of these differences is statistically significant, it is hard - for us at least - to see any clear pattern of ideologically-based bias in these numbers. And on the other policy questions-regarding the tax share, whether the payroll tax is larger than the income tax, the value of the minimum wage and whether respondents were aware of the Bush Social Security proposal-ideological differences were trivial and consistent with chance.

\section{Opinions on economic policy issues}

As stated earlier, the survey instrument began with a series of questions about people's opinions on a variety of economic policy issues.

\section{The Tax Burden and the Bush Tax Cuts}

The first such question was:

- Do you think taxes in the United States are generally too high, too low, or about right?

This question was asked, on a randomized basis, either before or after the fact question about the tax share. The ordering of the two questions turned out not to affect the responses appreciably, so we treated all the responses as a single sample. Some $61 \%$ of respondents said that taxes are too high, $36 \%$ said they are about right, $3 \%$ said they are too low, and $2 \%$ don't know. 
The overwhelming popular sentiment that taxes are too high can hardly come as a shock to any sentient American. We have probably believed this since the 1770s. But the cross-tabulations by subsets of the population did hold some surprises. First, selfdescribed conservatives were no more likely than the population as a whole to say that taxes are too high. Liberals, however, were notably less likely-just 48\%. The most antitax group turned out to be those disengaged non-politicals $(70 \%$ of whom said taxes are too high). Second, while racial differences were not terribly sharp, non-whites were more likely than whites to say that taxes are too high $(\mathrm{p}=.036)$. Third, lower-income people were more likely than higher-income people to say that taxes are too high (by $68 \%$ to $56 \%, \mathrm{p}=.001) .{ }^{35}$ Two other breakdowns were statistically significant: college-educated people were much less likely to say that taxes are too high (by $51 \%$ versus $65 \%, \mathrm{p}=.000$ ), and employed people were more likely (by $65 \%$ versus $56 \%$, p=.033).

While our survey was in the field, Congress was debating President Bush's 2003 tax proposal (which subsequently passed) to advance the timing of the phased-in tax-rate reductions that had been enacted in 2001 and to establish a preferentially-low tax rate on dividends. So we asked respondents whether they favored or opposed this proposal, ordering this opinion question (on a randomized basis) either before or after the fact question about whether the typical American pays more in payroll or income taxes. ${ }^{36}$ In this case, the answers did depend a bit on the ordering: Asking the payroll tax question first reduced support for the Bush tax cut by about five percentage points. But a chisquare test did not reject the null hypothesis of the independence of responses and question order $(p=0.31)$.

Looking for differences by individual characteristics, we found that political ideology mattered quite strongly $(p=.000)$. This time, conservatives were far more supportive of

\footnotetext{
${ }^{35}$ It has been suggested to us that, even though the rich pay higher average tax rates, the utility loss from paying taxes may be proportionately greater for the poor.

${ }^{36}$ Note, however, that this question always came after the question about the tax share.
} 
the Bush proposal (64\%) than other groups (36\%) —even though, as we have just seen, they were no more likely to deem taxes too high. Both the college-educated and selfreported voters were more likely to oppose the 2003 Bush tax cuts $(p=.000$ and $p=.003$, respectively), and both whites and higher-income people were much more likely to favor them ( $p=.000$ in both cases). Finally, employed people favored the Bush tax cuts more than non-employed people did. There were no significant differences by age or sex.

\section{The Federal Budget Deficit}

The next opinion question was:

- How much of a problem do you think the federal budget deficit poses for the economy? Would you say it is not a problem at all, a minor problem, or a serious problem?

We posed this question in two variants. In one case, we asked it after first inquiring about the size of the deficit. In the other case, we asked it after telling the respondent that "This year's federal budget deficit is approximately $\$ 300$ billion. This works out to around $\$ 3,000$ per household." Remember, the median estimate of those who were asked to estimate the size of the deficit was only $\$ 90$ billion. So giving the $\$ 300$ billion figure framed the deficit at a higher level for most respondent.

Telling respondents the actual size of the deficit did have a marked effect on their responses, as Table 10 shows. But oddly, doing so reduced the fraction who thought the deficit is a serious problem by about 9 percentage points. However, the $\chi^{2}$ test for independence between order and response categories was only marginally significant (pvalue $=.06)$.

We followed this question with two further queries about public policy toward the deficit:

- Do you think the federal budget deficit ought to be reduced?

- Do you think the deficit should be reduced mostly by raising taxes, mostly by cutting spending, or about equally by both means? 
The second question was asked only of those who answered "yes" to the first, which was $87.5 \%$ of the sample. Our respondents divided approximately evenly between those who favored "mostly by cutting spending" (45\%) and those who favored "about equally by both means" (47\%) — with a tiny minority (3\%) favoring "mostly by raising taxes." (The other 5\% gave no coherent opinion.) Looking at population subgroups:

Demographics: Older people and women were far more likely than younger people and men to rate the deficit "a serious problem" - by almost-identical 65\%-to-50\% margins $(p=.000)$. But ironically, and perhaps inconsistently, this belief did not make them more likely to "think the federal budget deficit ought to be reduced." Nor were there significant gender or racial differences in the preferred cures for the deficit; but older Americans favored expenditure cuts more than younger Americans did. Finally, while whites worried less about the budget deficit than did nonwhites, they were nonetheless slightly more likely to favor reducing the deficit.

Economic status: The opinions of college-educated and non-college-educated respondents did not differ significantly on any of the three deficit-related questions. And the same was true when we compared the employed to the non-employed. However, lower-income people were considerably more likely than higher-income people to rate the deficit a serious problem (by $65 \%$ versus $53 \%, \mathrm{p}=.012$ ). That said, income did not significantly influence opinion on either of the other two deficit-related questions.

Political involvement: Unsurprisingly, political ideology mattered quite a bit $(p=.000)$. In a sign of these unusual times, liberals were far more likely to rate the budget deficit a serious problem $(72 \%)$ than either conservatives $(44 \%)$ or non-politicals $(56 \%) .{ }^{37}$ In this

\footnotetext{
${ }^{37}$ By contrast, an NBC/Wall Street Journal poll of 1,003 adults conducted in January 1995 found that 40 percent of conservatives identified the federal budget deficit as the most important economic issue facing the country, while only 23 percent of liberals did so. By a wide margin, the deficit was the most commonly cited issue by conservatives, but not by liberals ( $38 \%$ of whom cited unemployment) See Roper Center, Public Opinion Online Archive, University of Connecticut, Question ID USNBCWSJ.012095, R09A.
} 
respect, moderates (at 67\%) were closer to liberals. Yet, once again, there were no significant differences by ideology in the fraction of people who "think the federal budget deficit ought to be reduced." (Almost everyone does.) Ideology showed through strongly again $(p=.000)$, however, when it came to selecting the preferred method for reducing the deficit. For example, conservatives favored spending cuts over tax increases by a margin of $50 \%$ to $2 \%$; among liberals, the corresponding margin was "just" $39 \%$ to $12 \%$. Finally, "voters" and nonvoters did not differ much on any of the three deficit-related questions.

The Minimum Wage

Our next query was straightforward:

- Do you think the federal minimum wage should be increased?

The answers overwhelmingly favored a higher minimum wage:

$\begin{array}{lr}\text { Yes } & 75 \% \\ \text { No } & 21 \% \\ \text { Don't know/refused } & 4 \%\end{array}$

We posed this question either before or after asking people what the current minimum age is, on a randomized basis. But the ordering made no difference. Disaggregating the sample by personal characteristics, we found:

Demographics: There were no significant differences in the answers to this question by age or employment status. But women and nonwhites were more likely to favor raising the minimum wage than men and whites - by margins of $81 \%$ to $69 \%(p=.000)$ for women and $93 \%$ to $74 \%(\mathrm{p}=.000)$ for nonwhites.

Economic status: College-educated people were less likely to favor a higher minimum wage than the not-college-educated (by $66 \%$ to $83 \%, \mathrm{p}=.000$ ). Perhaps they learned about

\footnotetext{
${ }^{38}$ The disengaged non-political group were like the conservatives in this respect. Moderates were in between.
} 
the alleged disemployment effects of the minimum wage in a college economics course! ${ }^{39}$ And, as you would expect, lower-income people favored raising it more than higherincome people did (by a margin of $85 \%$ versus $73 \%, p=.001$ ).

Political involvement: Not surprisingly, attitudes toward the minimum wage differed significantly by political ideology $(p=.000)$. Conservatives, though still supportive (at $60 \%$ ), were far less likely to favor raising it than were all other groups (which were in the $85-89 \%$ approval range). Self-reported voters were also less likely to favor raising the minimum wage (by $74 \%$ versus $87 \%, \mathrm{p}=.000$ ).

\section{Social Security policy}

In addition to the three fact questions mentioned above - pertaining to average Social Security benefits, the actuarial deficit, and President Bush's partial privatization planwe asked two policy questions about Social Security. First, immediately after asking, "Are you aware that President Bush has proposed that part of Social Security be replaced by personal investment accounts?," we posed the policy question:

- Do you favor or oppose this idea, or are you undecided?

Second, right after asking "Are you aware that the Social Security System is projected to start running deficits about a decade from now?," we inquired:

- Do you think the government should try to reduce those deficits mainly by raising the payroll tax, mainly by reducing Social Security benefits, or both?

Twenty percent of respondents favored partially replacing Social Security with personal accounts, while 38 percent opposed the idea and 42 percent were undecided. As for closing the future Social Security deficit, respondents were roughly evenly divided between those who favored a mixture of both remedies (34\%) and those who favored relying mainly on the payroll tax (30\%). Only $5 \%$ wanted to rely mainly on benefit

\footnotetext{
${ }^{39}$ The argument can be found in most beginning economics texts. For contrary evidence, see Card and Krueger (1995). A survey by Fuller and Geide-Stevenson (2003) in fall 2000 found that $46 \%$ of members of the American Economic Association "mainly agreed" that, "Minimum wages increase unemployment among young and unskilled workers." Twenty-seven percent disagreed, and $28 \%$ agreed with provisos.
} 
reductions, and a large $22 \%$ were undecided. Interestingly, this expressed preference for higher taxes over lower expenditures is just the reverse of what we found earlier, when we enquired about ways to reduce the overall budget deficit. Social Security, it appears, really is different.

Looking across subgroups, we found:

Demographics: There were no significant racial differences on either Social Security policy question. Men were much more likely to favor partial privatization than women (by $28 \%$ versus $13 \%, \mathrm{p}=.000$ ), and they were also less likely to favor tax increases to reduce the Social Security deficit (by $28 \%$ to $38 \%, \mathrm{p}=.000$ ). But the biggest differences, as one would expect, came by age. Older people were much more likely to oppose the privatization idea (by $46 \%$ versus $31 \%$ ) and much less likely to be undecided (by $32 \%$ versus $50 \%$ ). The curious consequence is that the proportion favoring the idea was roughly independent of age (about 20\%). When it came to choosing between benefit cuts and tax increases as alternative ways to reduce the Social Security deficit, older Americans were more likely to choose "neither" (by $31 \%$ versus $18 \%$ ) — even though that option was not offered in the question! Younger American were more likely to opt for "both" (by 45\% versus 29\%). Both sets of differences are highly significant.

Economic status: Higher income people were much more likely to favor privatization (by $27 \%$ versus $12 \%, \mathrm{p}=.000$ ), as were the employed (by $24 \%$ versus $15 \%$, $\mathrm{p}=.007$ ), and the college-educated (by $33 \%$ versus $16 \%, \mathrm{p}=.000$ ). Differences by education were interesting. The percentages of college-educated and non-college-educated respondents opposing the Bush privatization proposal were about the same (roughly $38 \%$ ). But many fewer of the college educated were undecided ( $28 \%$ versus $46 \%$ ). There were no significant differences on how best to reduce the looming Social Security deficit-no group wanted to see benefits cut. 
Political involvement: Ideology is pretty much a no-brainer on this issue:

Conservatives were vastly more likely to favor partial privatization (40\%) than either liberals $(9 \%)$, moderates $(18 \%)$, or non-politicals $(8 \%)$. Those who claim to have voted in the 2000 election were much more likely to favor privatization (by $25 \%$ versus $10 \%$ ) and much less likely to be undecided (by $35 \%$ versus $54 \%$ ). These differences are highly significant $(\mathrm{p}=.000)$. But again, the subgroups did not differ significantly in how they want to reduce the Social Security deficit. Those who were aware of the President's proposal were more inclined to support it (by 31\% versus 7\%). 
We asked people whether Medicare currently included an outpatient drug benefit. (It did not at the time of the survey.) We followed that query by asking those who thought it did not (74\% of all respondents):

- Would you favor or oppose adding a prescription drug benefit to Medicare for people who are not in the hospital, bearing in mind that it would have to be paid for somehow?

Despite the last clause, which we deemed important, the general view was overwhelmingly supportive, with $80 \%$ in favor and only $12 \%$ opposed. ${ }^{40}$ And opinions on this issue did not differ significantly by age (which we found surprising), sex, race, employment status, income, or self-reported voting behavior. College-educated people were a bit less likely to favor a Medicare drug benefit (by $82 \%$ versus $89 \%$ ), but the difference was barely significant $(\mathrm{p}=.033)$. The only highly-significant difference was by political ideology, but the ordering here was somewhat counterintuitive: The proportion favoring a Medicare drug benefit was 95\% among liberals, $89 \%$ among non-politicals, $85 \%$ among conservatives, and 79\% among moderates.

The other health policy question was:

- Do you favor or oppose what is called "universal health insurance coverage," meaning that the government would make sure that every American is covered by a health insurance policy?

Remember, asking about the number of uninsured Americans elicited a gross overestimate of the extent of the problem. Such a misconception might be expected to reduce support for universal coverage; but over $71 \%$ of our respondents favored it anyway. ${ }^{41}$ On this policy issue, differences of opinion across subgroups were the rule rather than the exception:

\footnotetext{
${ }^{40}$ The rest did not know or gave no opinion. Of course, as was pointed out at the Brookings panel meeting, we did not specify a particular way to pay for the drug benefit.

${ }^{41}$ However, the ordering of the questions mattered significantly in this case. When the policy question was asked before the inquiry about the number of uninsured, our respondents favored universal health insurance
} 
Demographics:Women were substantially more likely to favor universal health insurance than men (by $80 \%$ to $71 \%, \mathrm{p}=.003$ ), and nonwhites were much more likely to favor it than whites (by $87 \%$ versus $72 \%, p=.001$ ). But there were no significant differences by age.

Economic status: Low-income people were much more supportive of universal coverage than were high-income people (who were probably covered in any case), by a margin of $80 \%$ to $70 \%(p=.000)$. And people without a college degree were significantly more likely to favor universal coverage than college graduates (by $78 \%$ to $68 \%, \mathrm{p}=.001$ ). But surprisingly, employment status did not matter.

Political involvement: The politically-disengaged nonvoters were much more likely to favor universal health insurance than were "voters," by a margin of $85 \%$ to $71 \%$ $(p=.000)$. Ideology mattered, too. Liberals strongly favored universal coverage $(90 \%)$, while conservatives barely favored it (just 52\%). Moderates (79\%) and non-politicals (87\%) fell in between, but much closer to the liberals $(p=.000)$.

\section{Econometric Models of Knowledge and Public Opinion}

We return now to the five-equation model outlined earlier. Our primary interest is in equations like (1), which explain people's opinions on policy issues (OP) by their selfinterest (SI), ideology (ID), knowledge (K), education (ED), and other demographic controls (X). Recall that we identify the models by assuming a recursive structure. Readers unwilling to accept this assumption may be skeptical of our interpretation of the regression results - which is why we have reported only descriptive cross-tabulations up to now.

by a margin of $74 \%-22 \%$. When the ordering of the question was reversed, the margin fell to $67 \%-25 \%$. So getting people to think about the magnitude of the problem did suppress support a bit. 


\section{Does information breed knowledge?}

We begin with estimates of equation (2), which explains our admittedly imperfect measure of knowledge by information sources (quantity and nature), the desire to be informed, education, and other demographic variables. We tried measuring the respondents' sources of information in several ways: (a) by $\mathrm{Q}_{\mathrm{H}}$ and $\mathrm{Q}_{\mathrm{L}}$, the two intensityof-use variables defined earlier; (b) by the primary source of information; and (c) by a set of 22 dummy variables indicating, for each of the 11 sources, whether the respondent uses that source "regularly" or "occasionally". In the case of (c), we found that, once demographics were controlled for, the 22 source dummies were jointly insignificant (at the $10 \%$ level). So we eliminated option (c) and concentrated on the other two.

Table 11 begins with a linear regression with $\mathrm{K}$ on the left-hand side and only $\mathrm{Q}_{\mathrm{H}}, \mathrm{Q}_{\mathrm{L}}$, and demographics on the right-hand side (column 1). The fit is mediocre $\left(\mathrm{R}^{2}=0.17\right)$, and $\mathrm{Q}_{\mathrm{H}}$ and $\mathrm{Q}_{\mathrm{L}}$ are jointly insignificant—a result anticipated by Table 9. More educated people, higher-income people, and married people are significantly more knowledgeable.

Column 2 adds a set of three dummies indicating (in descending order) the respondent's desire to be informed. All three are significant at the 5\% level, and the pattern of the coefficients means that people with more desire to be informed do obtain higher knowledge scores. But the adjusted $\mathrm{R}^{2}$ barely increases.

In column 3, we add a set of political ideology and interest variables. Liberals, conservatives, and moderates (the control group) are no different in terms of knowledge. But people who haven't thought about their ideology score significantly lower (though only at the $10 \%$ level of significance). People who report themselves to have voted score significantly higher.

Finally, in a fourth regression not displayed here, we added ten dummies for the most important source of information. Three of the ten coefficients (for newspapers, magazines, and economists) are significant at the $10 \%$ level, and each indicates higher 
scores than the base group (which is television). The F-test for the ten dummies as a group also indicates statistical significance $(\mathrm{F}=1.88, \mathrm{p}=.045)$. The other results hardly change.

Thus our overall conclusion is that both education and the desire to be informed affect an individual's knowledge positively, although the magnitude of the education effect is modest. ${ }^{42}$ The nature of the respondent's primary source of information does affect his or her K score, but the general intensity of information use does not. To educators, these results must be considered somewhat disheartening, although we acknowledge that the brief test embedded in our survey assesses only a limited range of factual knowledgeand that, even as such, the test is highly imperfect.

Who believes what? And why?

For each of the five policy areas mentioned above, we now seek to estimate the relative roles of self-interest, ideology, and knowledge in forming public opinionequations (1) in the model. In some sense, this is the natural culmination of our enquiry, since information usage and knowledge are, in this context, just way-stations on the road to public opinion.

\section{The Bush Tax Cuts}

Because $31 \%$ of respondents offered intermediate responses (either a mixed opinion or no opinion), we estimated ordered probit models for opinion on the 2003 Bush tax cut proposals with three choices: oppose, mixed response, or favor-in ascending order. Thus positive coefficients in Table 12 indicate more favorable attitudes toward the Bush tax cuts. The magnitudes of the estimated coefficients in an ordered probit model are not easy to interpret, but the relative magnitudes are. For example, we see in column 1 that

\footnotetext{
${ }^{42}$ Four more years of education raise the test score by $4-5$ points, or about one-quarter of a standard deviation.
} 
the coefficient of the dummy variable for being black is ten times as large as the coefficient for years of education. That means that being black has the same effect on the underlying probabilities as ten more years of education.

The estimates reported in Table 12 are interesting and, for the most part, indicative of what we will learn later about opinion on other policy issues. Column 1 begins by trying to explain attitudes toward the tax cut by purely demographic variables, plus (log)

income. Since the tax cut proposal was highly regressive, household income should be an excellent measure of self-interest here. ${ }^{43}$ The model does not explain much - the pseudo$\mathrm{R}^{2}$ measure of goodness-of-fit is below 0.02 . Furthermore, virtually none of the demographic variables in column (1) matter. More educated people and blacks are more opposed to the tax cuts. That's about it. ${ }^{44}$ (Remember, when we looked at simple correlations, several demographic variables were significant.) While household income gets the correct sign in all three models in Table 12 - that is, richer people do favor the tax cuts more - the coefficient is never significant. Where have you gone, homo economicus $?^{45}$

Column 2 adds a host of ideology and knowledge variables. Many of them are significant, and the pseudo- $\mathrm{R}^{2}$ jumps dramatically to $0.12 .{ }^{46} \chi^{2}$ tests (reported in square brackets in the table) clearly show that both ideology and knowledge are strongly associated with opinions on the tax cuts.

Ideology is measured both by political ideology, as discussed above, and by opinions on (a) whether the tax burden is too high or too low and (b) whether taxes should be

\footnotetext{
${ }^{43}$ Unlike the case of the 2001 tax cut, the 2003 tax cut offered virtually no benefits to low- and moderateincome taxpayers.

${ }^{44}$ Among our four controls for marital status (not shown in the table), one is significant ( $\mathrm{p}$-value $=.01$ ): divorced and separated people are more likely to favor the Bush tax cuts.

${ }^{45}$ Both Bartels (2003) and Slemrod (2003) emphasize the role of popular misconceptions in generating public opinion on tax policy in general and on the Bush tax cuts in particular. Slemrod finds that more educated people suffer somewhat less from these misconceptions.

${ }^{46}$ This is not an entirely clean comparison since the sample size drops from 874 to 722 observations owing to missing data.
} 
progressive. ${ }^{47}$ Column 2 of Table 12 shows that ideology matters quite a lot.

Conservatives are much more favorably disposed toward the tax cuts, and liberals are much more opposed (compared to the base group, which was moderates). Similarly, those who think taxes are too high are vastly more likely to favor the Bush tax proposal than are those who think taxes are too low. ${ }^{48}$ (In this case, the omitted group is: taxes are about right.) Finally, those who believe taxes should be progressive are less likely to favor the Bush proposal, though this coefficient becomes insignificant in the model in column 3 .

Knowledge is measured in two ways: general and specific to tax policy. Our constructed K score measures general knowledge. Specific knowledge about taxes is measured by (a) the estimated tax share and (b) whether the respondent knows that most people pay more in payroll taxes than in income taxes. (Remember, these two indicators of specific knowledge are also part of the general knowledge score.) While general knowledge matters in the estimated model, specific knowledge about taxes does not—and most of the coefficients appear to be incorrectly signed. (The finding about general knowledge is the one result in Table 12 that is not typical of what is to come.) The $a$ priori "correct" sign on the coefficient of $\mathrm{K}$ is unclear, since the composite score measures knowledge of facts, not of economic theory, labor supply elasticities, or anything like that. But those with more factual knowledge about the economy apparently are less supportive of the Bush tax cut proposal, ceteris paribus.

In column 3, we add a pair of dummy variables for whether the respondent believes the budget deficit is a major problem or a minor problem (the omitted category is "no problem at all"). It seems obvious that views on this question should influence support

\footnotetext{
47 The precise question is: "Do you agree or disagree with the statement that higher income households should pay a larger share of their income in taxes than lower income households?"

${ }^{48}$ Readers can decide for themselves whether they want to think of this as an "ideology" variable. But remember, the regression already controls for the estimated tax share.
} 
for the Bush tax cuts - and they do. However, the standard identification assumption may be difficult to sustain in this case. It seems quite possible that, say, some unmeasured influence (call it "liking George Bush") that makes a respondent favor the Bush tax cut also makes him downplay the importance of budget deficits. Hence, some readers may prefer to ignore column 3. Fortunately, including or excluding these two variables does not change the other coefficients much.

\section{$\underline{\text { Reducing the Federal Budget Deficit }}$}

As just mentioned, we began this part of the questionnaire by asking all respondents how much of a problem they think the federal budget deficit poses. ${ }^{49} \mathrm{We}$ ordered the three possible responses in ascending order of concern about the deficit: no problem at all, a minor problem, or a serious problem. So positive coefficients in the ordered probit estimates of Table 13 indicate greater concern.

As the reader may recall, about half the respondents were asked how large they think the deficit is, but fewer than half answered the question. So, while it seems sensible to use the estimated deficit as a regressor, doing so would shrink the sample by more than three-quarters. For this reason, Table 13 presents only regressions that exclude the estimated deficit variable. Suffice it to say that equations that included the estimated deficit (a) showed that people who think the deficit is larger are more worried about it and (b) including the estimated deficit does not change the signs of the other coefficients.

As before, we start with an initial model that includes only demographic variables plus the only self-interest variable we could think of for the deficit issue: income-which becomes insignificant once we control for ideology (see column 2). The fit is poor, though better than in Table 12. Women, blacks, older people, and more-educated people are more concerned about the deficit (the latter barely so).

\footnotetext{
${ }^{49}$ There was a more direct policy question--whether the respondent thought the deficit should be reduced - but the vast majority of respondents answered yes, making the answers rather uninteresting to analyze.
} 
The ideology variables, which are added in column 2, are more interesting - and adding them more than doubles the pseudo- $\mathrm{R}^{2}$. Conservatives are less concerned about the deficit than are liberals and moderates, and those with "other" ideologies look a lot like conservatives in this respect. Similarly, people who favor progressive taxationanother way to identify liberals? - are significantly more concerned. People who think taxes are too high are more worried about the deficit, while people who think taxes are too low are less worried. (Column 3 shows that the first of these coefficients is significant at the 5\% level, while the second is not.) This finding may indicate that many respondents expect the eventual cure for the deficit problem to be higher taxes. When it comes to knowledge, neither our composite score nor specific knowledge about taxes affect opinion on the deficit significantly.

Opinions vary greatly on the methods that should be used to reduce the deficit. Here we estimated two probit models, both shown in Table 14, running the model only on the subset of respondents who said the deficit ought to be reduced. Since the choices were "raising taxes", "cutting spending", or "both", we created two binary variables:

$$
\text { Taxes }=1 \text { if the respondent chose raising taxes or both }
$$
$=0$ otherwise

Spending $=1$ if the respondent chose cutting spending or both $=0$ otherwise

and estimated an ordinary probit model for each. The model for "Spending" is less interesting, however, since almost everyone thinks spending cuts should be part of the solution, while our respondents split almost 50-50 on whether higher taxes should be part of the solution.

What do we find? Beginning with self-interest, higher-income people are slightly less likely to favor raising taxes and slightly more likely to favor cutting spending. But neither coefficient is generally significant. Thus, once again, self interest seems to matter little. And in this case, ideology also matters rather less than might be expected: Liberals and 
people of "other" ideologies are far less likely to favor cuts in spending. Naturally, people who believe that taxes are already too high are far less likely to favor the tax-hike alternative and far more likely to favor spending cuts; and those who think taxes are too low hold the opposite views. Self-professed voters are less enthusiastic about cutting spending and a bit more enthusiastic about raising taxes than are non-voters, but the coefficients are not always significant. Respondents with higher levels of general economic knowledge are marginally less likely to favor tax hikes. And those who (wrongly) believe that income taxes are typically larger than payroll taxes are much less enamored of tax hikes. Among the demographic variables, the only consistently significant effect is that older people are less likely to favor raising taxes.

\section{Raising the Minimum Wage}

Table 15 displays a series of ordinary (binary) probit models to explain support for raising the minimum wage. Separating self-interest from some of the demographic determinants of opinion is tricky in this case because our survey offers no direct information on respondents' wage rates. We do, however, measure several obvious correlates of wages such as income, race, sex, and education — all of which show up as significant determinants of opinion in column 1 . In each case, the sign of the coefficient is consistent with the simple hypothesis that lower-wage people are more likely to favor raising the minimum wage than higher-wage people. Apart from these potential wage proxies, the demographic variables are insignificant.

Following the pattern of previous tables, columns 2 and 3 of Table 15 add ideology and knowledge variables to the model. While ideology once again contributes notably to explaining opinion, only conservatives stand out from the pack in being less favorably disposed toward raising the minimum wage.

The knowledge variables are more interesting. General knowledge is irrelevant, but people who believe the existing minimum wage is higher are decidedly less likely to 
support raising it. Similarly, those who believe that a higher minimum wage would cause the loss of either "a lot of" (6\% of the sample) or "some" jobs (36\%) are much less likely to favor raising it than are those who believe that "hardly anyone" would lose their job ( $57 \%$ of the sample). Comparing columns 2 and 3 shows that these three "specific knowledge" variables contribute enormously to the goodness of fit.

The minimum wage is arguably the one policy that we have examined where a good case can be made that self-interest—or, at least, group interest—and economic beliefs and knowledge are as strong an influence on public opinion as ideology. For example, when the estimated coefficients shown in column 3 are translated into marginal effects on probabilities, we find that self-identified conservatives are 13 percentage points less likely than liberals to support a minimum wage increase. Similarly, support for an increase is 14 points higher for blacks than for whites, 16 points higher for those in the poorest $15 \%$ of households than for those in the richest $15 \%, 10$ points higher for women than for men, and an impressive 58 points higher among those who believe that a lot of workers will lose their jobs from an increase than among those who believe hardly anyone will lose their job.

\section{$\underline{\text { Social Security Policy }}$}

We asked two questions about Social Security policy: whether respondents support President Bush's plan for partial privatization, and how (if at all) the Social Security deficit should be reduced.

Where Social Security was concerned, we included several novel self-interest variables, in addition to income, in the survey. (See the upper portion of Table 16.) Broadening the concept of self-interest just a bit, we asked whether the respondent's mother, father, or both were still alive. We also asked respondents whether they expected Social Security to be a "major source" of retirement income, a "minor source", or "not much of a source at all”. Presumably, people in the first category have a much greater 
stake in the outcome of the Social Security debate. And older workers should have more of a stake in the current system.

When it comes to attitudes toward personal accounts, the subjective self-interest measure of anticipated Social Security income "works," while the more objective onesincome, whether the parents are alive, and age — have inconsistent and weak effects, although they are sometimes significant in the expected direction. The $\chi^{2}$ tests for the entire group of self-interest variables show statistical significance beyond the $1 \%$ level in columns 2 and 3, and the importance of Social Security benefits in retirement income is significant in all specifications.

The knowledge variables - whether general or specific to Social Security — make little contribution to explaining opinions on privatizing Social Security. As noted earlier, respondents who are aware of President Bush's proposal are more likely to support it; but the difference is not significant $(\mathrm{p}$-value $=.19)$. More educated people are slightly more likely to favor partial privatization.

Political ideology matters much more than knowledge. Not surprisingly, conservatives are much more likely to back privatization and liberals are more likely to oppose it.

In the questions about how to reduce the actuarial deficit, the choices were "mainly by raising the payroll tax" (chosen by $30 \%$ of respondents), "mainly by reducing Social Security benefits" (5\%), or "both" $(34 \%) .{ }^{50}$ We created two dummy variables analogous to the two we created for deficit-reduction policy:

$$
\begin{aligned}
& \text { SS-Taxes } \quad=1 \text { if the respondent chose raising payroll taxes or both } \\
& =0 \text { otherwise } \\
& \begin{aligned}
\text { SS-Spending } & =1 \text { if the respondent chose cutting benefits or both } \\
& =0 \text { otherwise, }
\end{aligned}
\end{aligned}
$$

and ran binary probit models for each. The results are displayed in Table 17.

\footnotetext{
${ }^{50}$ We excluded those who did not answer ( $9 \%$ of the sample) and those who said "neither" $(22 \%)$.
} 
Our ability to explain people's opinions on this important public policy issue is quite modest (pseudo- $\mathrm{R}^{2} \mathrm{~s}$ are in the $.06-.07$ range in both cases). Surprisingly, and in contrast to the results in Table 16, the six self-interest variables are not significant determinants of opinion, either individually or as a group, once political ideology variables are included. Nor does ideology itself matter very much. (The $\chi^{2}$ statistics are insignificant in all cases.) Knowledge does matter, however. Respondents with higher general knowledge are a bit less likely to favor raising the payroll tax, and people with higher estimates of monthly Social Security benefits are, surprisingly, less likely to want to cut them. (But the coefficient is barely significant at the $10 \%$ level.) Interestingly, those who say they are aware of President Bush's privatization proposal, are significantly (at the 5\% level) less willing to cut Social Security benefits.

On the demographics, women and students are significantly less inclined to cut benefits, while Hispanics are (barely) significantly more inclined. Unemployed people are decidedly less enthusiastic than others about raising payroll taxes.

\section{Health insurance policy}

Our last two policy questions pertain to health insurance. As mentioned above, we asked respondents whether they favored adding a prescription drug benefit to Medicare and whether they favored universal coverage.

In addition to age and income, the survey included what we believed would be useful self-interest variables tailored to these questions. We asked whether the respondent's parents are alive, and whether the respondent or anyone in his or her immediate family is uninsured. We begin with Table 18, which displays the results for an ordinary probit model of opinion on universal health insurance coverage.

Higher-income people are significantly more opposed to universal coverage $(p=.000)$, and uninsured respondents are more likely to favor it $(p=.004$ in column 1 , but $p=.108$ in 
column 2). ${ }^{51}$ However, neither age nor having an uninsured family member affects one's opinion. The coefficients on own insurance coverage imply that people who lack health insurance are 12 points more likely to support universal coverage in column 1 and 8 points more likely in column 2. As usual, measures of political ideology are successful as regressors. Liberals are far more likely to favor universal coverage, and conservatives are much more likely to oppose it. Interestingly, those politically-engaged "voters" are less likely to favor universal coverage. Knowledge appears to have a modest effect on opinions on universal coverage. The general knowledge score is irrelevant, as usual. But people with higher estimates of the uncovered population are a bit more likely to favor universal coverage. ${ }^{52}$ Finally, demographic variables do not seem to matter-not even age. Blacks are more likely (than whites) to favor universal coverage in column 1 , but the coefficient becomes insignificant once ideology and knowledge are added to the equation (column 2).

In Table 19, we explore the determinants of public opinion on adding a prescription drug benefit to Medicare, limiting our sample to respondents who, at the time of the survey, knew that Medicare did not cover prescription drugs. Here, demographics matter more than they do on most other policy issues. Blacks and more-educated people are far less likely to support such a benefit, while students are much more likely to support it. The results on self-interest, ideology, and knowledge are by now familiar: self-interest and knowledge are not significant determinants of opinion, but political ideology is. In particular, liberals and respondents with "other" (than liberal, conservative, or moderate) ideology are substantially more likely to support a prescription drug benefit. So are selfprofessed voters, at least in two of the three specifications.

\footnotetext{
${ }^{51}$ Our results indicate more of an impact of self-interest on support for universal health insurance than was found in previous research. For example, Sears, et al. (1980) find that a respondent's support for government-funded national health insurance is unrelated to his own health insurance coverage.

${ }^{52}$ The coefficient implies that a 10 percentage point increase in the presumed uncovered population is associated with a 3 percentage point increase in support for universal health insurance.
} 


\section{Conclusion}

Taken as a whole, our survey results hold little good news for those of us engaged in economic education and/or economic policy_or for economic theorists who use homo economicus as the backbone of their models of political economy.

On the positive side, a representative national sample of Americans does express a strong desire to be well-informed about major economic policy issues. And their factual knowledge is, on average, reasonable. From where does their information come? The short answer is television, followed at a (long) distance by local (rather than national) newspapers. Unfortunately, as a source of information, television does far better on quantity than on quality. For example, it ranks eighth among the 11 possible sources of information in its contribution to our constructed measure of economic knowledge, although we recognize that one can question the direction of causality here. Perhaps more disconcerting, economic knowledge is barely higher in people who (a) use more sources of information, (b) use information more intensively, or (c) express a stronger desire to be informed. On the other hand, people with more education and more income are more knowledgeable.

As a broad generalization - to which many exceptions have been noted in this paperideology seems to play a stronger role in shaping opinion on economic policy issues than either self-interest or knowledge, although specific (as opposed to general) knowledge does influence opinion on a number of matters. ${ }^{53}$ This finding is not terribly different from the conclusion reached by Fuchs, Krueger, and Poterba (1998) in their survey of professional economists: Left-right ideology seemed to shape opinion more than parameter estimates did. The contrast with homo economicus - who is well-informed,

\footnotetext{
${ }^{53}$ Of course, our K variable measures knowledge with considerable error, which probably biases its coefficient downward.
} 
non-ideological, and extremely self-interested — could hardly be more stark. Instead, our findings seem more consistent with an idea expressed in the political science literature: that people often use ideology as a short-cut heuristic for deciding what position to take, when properly informing oneself is difficult. ${ }^{54}$

In closing, we offer two speculative explanations for this basic finding: confusion and generosity of spirit. Both explanations start from the premise that people typically develop conventional ("ideological") beliefs about how the world works and about what is good for them and for the commonweal. Thereafter, the two explanations diverge. The confusion explanation emphasizes how misperceptions of their own self-interest can lead people to act (or, in our case, to speak) against their best interests. ${ }^{55}$ The generosity explanation emphasizes that, at least when it comes to national economic policy, people are often more interested in what they perceive to be the common good than they are in their own narrow self-interest. ${ }^{56}$ In both cases, there is at least room for hope that greater knowledge will improve decisionmaking, even though it appears from our survey that efforts in this dimension have shown less than impressive results to date.

\footnotetext{
${ }^{54}$ See, for example, Lupia (1994).

${ }^{55}$ Bartels (2003) and Slemrod (2003) fall squarely within this camp. Romer (2003) provides a start at modeling political outcomes under the assumption that voters have systematic misperceptions.

${ }^{56}$ See Caplan (2002) and the essays in Mansbridge (1990) for further discussion of how group interests affect public opinion and voting.
} 


\section{Bibliography}

Bartels, Larry M. 2003. "Homer Gets a Tax Cut: Inequality and Public Policy in the American Mind.” Working Paper. Princeton University (August).

Black, Duncan. 1948. "On the Rationale of Group Decision-making.” Journal of Political Economy 56(1): 23-34.

Blendon, Robert J., John M. Benson, Mollyann Brodie, Richard Morin, Drew E. Altman, Daniel Gitterman, Mario Brossard, and Matt James. 1997. "Bridging the Gap between the Public's and Economists' Views of the Economy." Journal of Economic Perspectives 11(3): 105-118.

Blinder, Alan S. 1997. “Is Government Too Political?" Foreign Affairs 76 (November/December): 115-126.

Blinder, Alan S., and John Morgan. Forthcoming. "Are Two Heads Better than One?: Monetary Policy by Committee.” Journal of Money, Credit, and Banking.

Caplan, Bryan. 2002. "Sociotropes, Systematic Bias, and Political Failure: Reflections on the Survey of Americans and Economists on the Economy." Social Science Quarterly 83(2): 416-435.

Card, David, and Alan B. Krueger. 1995. Myth and Measurement: The New Economics of the Minimum Wage. Princeton, New Jersey: Princeton University Press.

Downs, Anthony. 1957. An Economic Theory of Democracy. New York: Harper and Row.

Fuchs, Victor R., Alan B. Krueger, and James M. Poterba. 1998. "Economists' Views about Parameters, Values, and Policies: Survey Results in Labor and Public Economics." Journal of Economic Literature 36(3): 1387-1425.

Fuller, Dan, and Doris Geide-Stevenson. 2003. "Consensus Among Economists: Revisited.” Journal of Economic Education (Fall): 369-387.

Gale, William G., and Jeffrey Rohaly. 2003. "Three-Quarters of Filers Pay More in Payroll Taxes Than in Income Taxes.” Tax Notes January 6: 119.

Hamilton, James. 2004. All the News That's Fit to Sell. Princeton, New Jersey: Princeton University Press.

Hansen, Karsten T., James J. Heckman, and Kathleen J. Mullen. Forthcoming. "The Effect of Schooling and Ability on Achievement Test Scores." Journal of Econometrics.

Kahneman, Daniel. 1986. "Comments." In Valuing Environmental Goods, edited by Ronald G. Cummings, David S. Brookshire, and William D. Schulze. Totowa, New Jersey: Rowman and Allanheld. 
Keeter, Scott, Carolyn Miller, Andrew Kohut, Robert Groves, and Stanley Presser. 2000. "Consequences of Reducing Nonresponse in a National Telephone Survey." Public Opinion Quarterly 64(2): 125-148.

Lupia, Arthur. 1994. "Shortcuts Versus Encyclopedias: Information and Voting Behavior in California Insurance Reform Elections." American Political Science Review 88(1): 6376.

Mansbridge, Jane, ed. 1990. Beyond Self-Interest. Chicago: The University of Chicago Press.

Monroe, Alan. 1979. "Consistency between Public Preferences and National Policy Decisions.” American Politics Quarterly 7: 3-19.

Mullainathan, Sendhil, and Andrei Shleifer. 2003. "The Market for News." Working Paper. Harvard University (December).

Page, Benjamin I., and Robert Y. Shapiro. 1983. "Effects of Public Opinion on Policy." American Political Science Review 77(1): 175-190.

Palfrey, Thomas R., and Keith T. Poole. 1987. "The Relationship between Information, Ideology, and Voting Behavior." American Journal of Political Science 31(3): 511-530.

Persson, Torsten, and Guido Tabellini. 2000. Political Economics: Explaining Economic Policy. Cambridge, Mass.: MIT Press.

Romer, David. 2003. "Misconceptions and Political Outcomes." The Economic Journal 113(484): 1-20.

Sears, David O., Richard R. Lau, Tom R. Tyler, and Harris M. Allen, Jr. 1980. "SelfInterest vs. Symbolic Politics in Policy Attitudes and Presidential Voting." American Political Science Review 74(3): 670-684.

Slemrod, Joel. 2003. "The Roles of Misconceptions in Support for Regressive Tax Reform.” Working Paper. University of Michigan (September).

Zaller, John. 1992. The Nature and Origins of Mass Opinion. Cambridge, England: University of Cambridge Press. 
Figure 1: Distribution of Knowledge Scores

Fraction

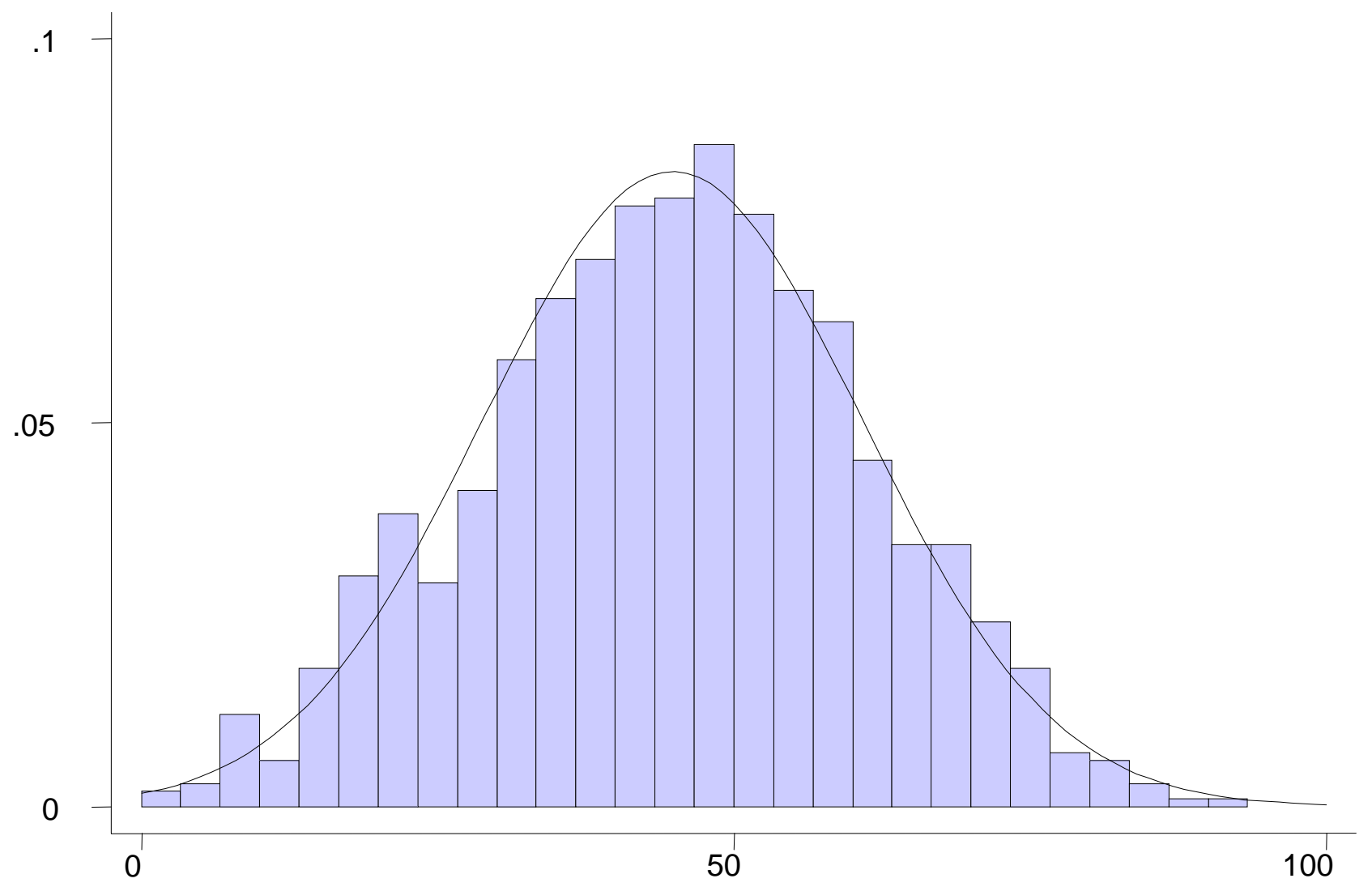

Knowledge Score 
Table 1

Reason

Reasons for Wanting to be Informed

Affects personal finances

Affects business or profession

Percent saying yes

Relevant to stock market, investments

$54 \%$

$7 \%$

Economic issues are important politically;

$4 \%$

$22 \%$

might affect my vote

To be a responsible citizen;

just like to keep informed

$55 \%$

NOTE: Respondents could offer more than one answer.

Table 2

Frequency of use of alternative sources of information

\begin{tabular}{|c|l|c|c|c|}
\hline Rank & \multicolumn{1}{|c|}{ Source } & $\begin{array}{c}\text { Percent } \\
\text { regularly }\end{array}$ & $\begin{array}{c}\text { Percent } \\
\text { occasionally }\end{array}$ & $\begin{array}{c}\text { Percent } \\
\text { rarely/never }\end{array}$ \\
\hline 1. & Television & 61 & 30 & 9 \\
\hline 2. & Newspapers & 49 & 26 & 25 \\
\hline 3. & Friends or relatives & 35 & 42 & 22 \\
\hline 4. & Political leaders & 35 & 40 & 25 \\
\hline 5. & Radio & 26 & 23 & 50 \\
\hline 6. & Economists & 17 & 36 & 46 \\
\hline 7. & Internet & 12 & 18 & 61 \\
\hline 8. & Business leaders & 10 & 31 & 57 \\
\hline 9. & Civic or religious leaders & 12 & 27 & 62 \\
\hline 10. & Magazines & 7 & 14 & 67 \\
\hline 11. & Books & 79 \\
\hline
\end{tabular}

Note: The three italicized sources of information are not themselves delivery channels; information from these sources must presumably arrive via one or more of the eight channels. 
Table 3

Most important sources of information

\begin{tabular}{|c|l|l|}
\hline Rank & Source & Percent \\
\hline 1. & Television & $46.7 \%$ \\
\hline 2. & Newspapers & $18.6 \%$ \\
\hline 3. & Internet & $10.0 \%$ \\
\hline 4. & Radio & $8.9 \%$ \\
\hline 5. & Friends and relatives & $6.6 \%$ \\
\hline 6. & Political leaders & $2.3 \%$ \\
\hline 7. & Magazines & $2.2 \%$ \\
\hline 8. & Civic or religious leaders & $1.2 \%$ \\
\hline 9. & Business leaders & $1.2 \%$ \\
\hline 10. & Economists & $1.1 \%$ \\
\hline 11. & Books & $0.5 \%$ \\
\hline
\end{tabular}

Note: The numbers indicate the percentage of respondents selecting that source as most important.

Table 4

Proportion Reading Various Newspapers, by Ideology

Haven't

Newspaper Liberal Conservative Moderate Thought $\underline{\text { P-value }}$

\begin{tabular}{|c|c|c|c|c|c|}
\hline NY Times & .23 & .03 & .09 & .02 & .000 \\
\hline Wall St. Jnl. & .05 & .10 & .09 & .03 & .001 \\
\hline Wash. Post & .06 & .01 & .01 & .00 & .000 \\
\hline USA Today & .08 & .07 & .12 & .04 & .013 \\
\hline Other Big City & .25 & .25 & .18 & .14 & .002 \\
\hline Local Newspaper & .44 & .55 & .56 & .56 & .066 \\
\hline
\end{tabular}

Note: P-value is for a test of the hypothesis that a constant proportion of members in all ideological groups use the particular source.

Table 5

Frequency Distributions of $\mathrm{Q}_{\mathrm{H}}$ and $\mathrm{Q}_{\mathrm{L}}$

\begin{tabular}{|c|c|c|}
\hline Range & $\begin{array}{c}\text { Frequency } \\
\text { for } \mathbf{Q}_{\mathbf{H}}\end{array}$ & $\begin{array}{c}\text { Frequency } \\
\text { for } \mathbf{Q}_{\mathbf{L}}\end{array}$ \\
\hline 0.0 to 0.1 & .320 & .055 \\
\hline 0.1 to 0.2 & .196 & .076 \\
\hline 0.2 to 0.3 & .205 & .114 \\
\hline 0.3 to 0.4 & .132 & .165 \\
\hline 0.4 to 0.5 & .070 & .179 \\
\hline 0.5 to 0.6 & .039 & .151 \\
\hline 0.6 to 0.7 & .025 & .124 \\
\hline 0.7 to 0.8 & .009 & .075 \\
\hline 0.8 to 0.9 & .004 & .042 \\
\hline 0.9 to 1.0 & .0003 & .019 \\
\hline
\end{tabular}


Table 6

Economic Knowledge: Actual versus Survey Estimates

\begin{tabular}{|l|c|c|c|c|}
\hline \multicolumn{1}{|c|}{ Question } & Actual & $\begin{array}{c}\text { Survey } \\
\text { Mean }\end{array}$ & $\begin{array}{c}\text { Survey } \\
\text { Std. Dev. }\end{array}$ & $\begin{array}{c}\text { Survey } \\
\text { Median }\end{array}$ \\
\hline Tax share & $23.3 \%$ & $31.3 \%$ & $15.6 \%$ & $30 \%$ \\
\hline Payroll or income tax is larger? & payroll $(83 \%)$ & income $(52 \%)$ & -- & income \\
\hline Size of budget deficit & $\$ 246-\$ 310 \mathrm{~b}$ & $\$ 334 \mathrm{~b}$ & $\$ 739 \mathrm{~b}$ & $\$ 90 \mathrm{~b}$ \\
\hline Level of minimum wage & $\$ 5.15$ & $\$ 5.86$ & $\$ 1.27$ & $\$ 5.65$ \\
\hline Size of SS check & $\$ 898$ & $\$ 824$ & $\$ 493$ & $\$ 800$ \\
\hline Know Bush SS proposal? & Yes & yes $(56 \%)$ & -- & yes \\
\hline Know SS deficits coming? & Yes & yes $(69 \%)$ & -- & yes \\
\hline Medicare drug benefit? & No & no $(54 \%)$ & -- & no \\
\hline $\begin{array}{l}\text { Percent without health } \\
\text { insurance }\end{array}$ & $15 \%$ & $37 \%$ & $16.7 \%$ & $35 \%$ \\
\hline
\end{tabular}

Table 7

Knowledge Score, by Desire to Keep Well-Informed

\begin{tabular}{|l|c|c|}
\hline $\begin{array}{c}\text { How important is it to } \\
\text { keep well-informed? }\end{array}$ & $\begin{array}{c}\text { Mean K score } \\
\text { (percentile) }\end{array}$ & \% of sample \\
\hline Extremely important & 43.8 & $23.8 \%$ \\
\hline Very important & 43.3 & $50.2 \%$ \\
\hline Somewhat important & 42.5 & $23.4 \%$ \\
\hline $\begin{array}{l}\text { Not very important or } \\
\text { not important at all }\end{array}$ & 34.5 & $2.6 \%$ \\
\hline
\end{tabular}

Table 8

Knowledge Score, Ranked by Most Important Source of Information

\begin{tabular}{|l|l|c|c|}
\hline Rank & Most important source & Mean K score & \% of sample \\
\hline 1. & Magazines & 52.7 & $2.2 \%$ \\
\hline 2. & Economists & 50.3 & $1.1 \%$ \\
\hline 3. & Newspapers & 46.8 & $18.6 \%$ \\
\hline 4. & Business leaders & 46.1 & $1.2 \%$ \\
\hline 5. & Internet & 45.9 & $10.1 \%$ \\
\hline 6. & Books & 43.7 & $0.5 \%$ \\
\hline 7. & Radio & 42.3 & $8.9 \%$ \\
\hline 8. & Television & 41.1 & $46.6 \%$ \\
\hline 9. & Political leaders & 40.9 & $2.3 \%$ \\
\hline 10. & Friends and relatives & 39.9 & $6.6 \%$ \\
\hline 11. & Civic/religious leaders & 35.0 & $1.2 \%$ \\
\hline
\end{tabular}




\section{Table 9}

Knowledge Score, Ranked by Number of Sources Used Regularly

\begin{tabular}{|c|c|c|}
\hline Number & Mean K score & \% of sample \\
\hline $5+$ & 45.5 & $14.4 \%$ \\
\hline 4 & 43.5 & $13.0 \%$ \\
\hline 3 & 46.1 & $20.9 \%$ \\
\hline 2 & 44.4 & $19.4 \%$ \\
\hline 1 & 39.4 & $21.2 \%$ \\
\hline 0 & 37.1 & $11.2 \%$ \\
\hline
\end{tabular}

\section{Table 10}

Opinions on How Big a Problem the Deficit Poses

\begin{tabular}{|l|c|c|c|}
\hline \multicolumn{1}{|c|}{ Opinion } & $\begin{array}{c}\text { Told the } \\
\text { Number }\end{array}$ & $\begin{array}{c}\text { Not told the } \\
\text { number }\end{array}$ & All \\
\hline A serious problem & $50 \%$ & $59 \%$ & $54 \%$ \\
\hline A minor problem & $38 \%$ & $33 \%$ & $36 \%$ \\
\hline Not a problem & $5 \%$ & $3 \%$ & $4 \%$ \\
\hline Don't know & $6 \%$ & $5 \%$ & $5 \%$ \\
\hline
\end{tabular}


Table 11

OLS Regressions for Economic Knowledge Scores (K)

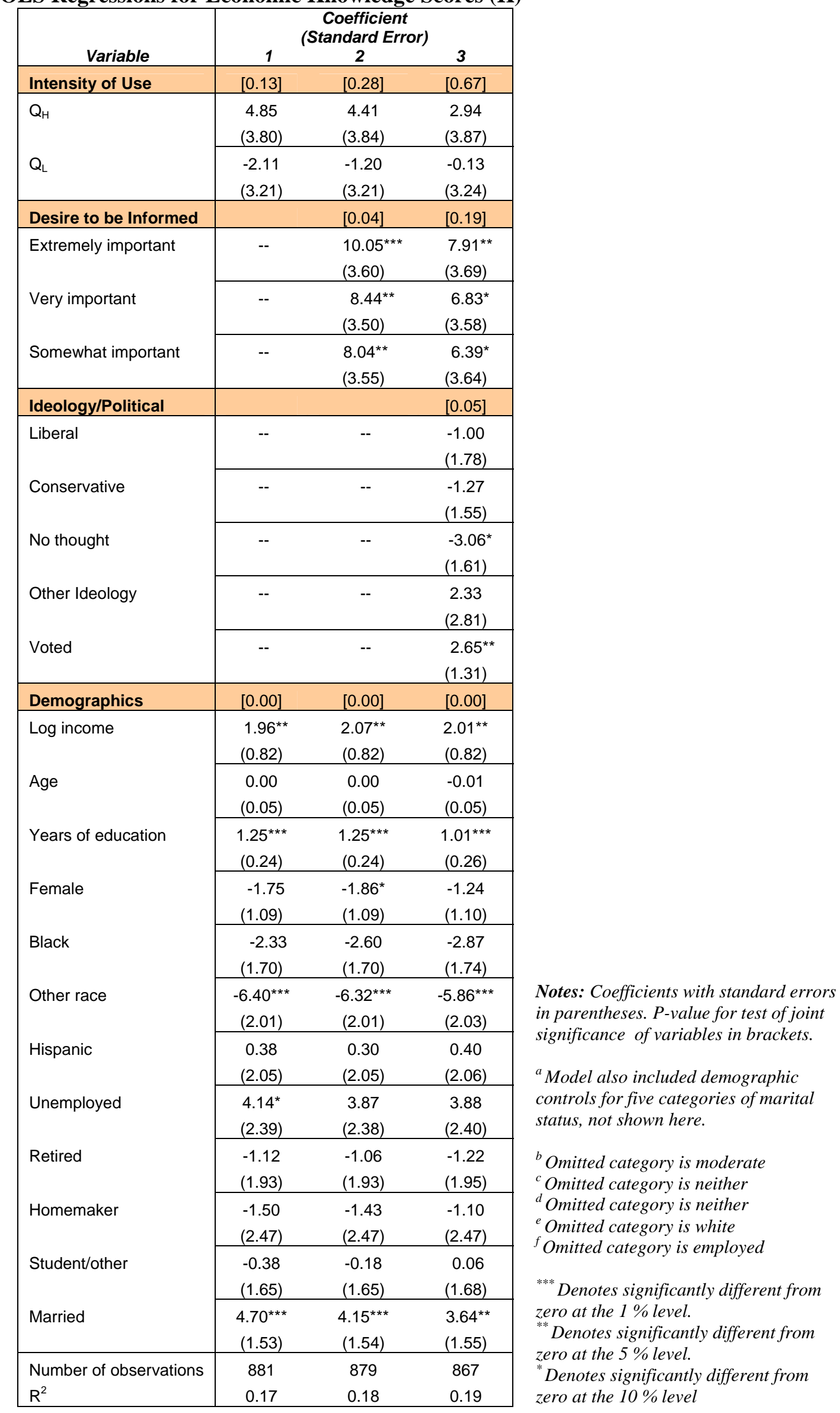


Table 12

Ordered probit model for favoring Bush tax cut

\begin{tabular}{|c|c|c|c|}
\hline \multirow[b]{2}{*}{ Variable } & \multicolumn{3}{|c|}{$\begin{array}{c}\text { Coefficient } \\
\text { (Standard Error) }\end{array}$} \\
\hline & 1 & 2 & 3 \\
\hline Self-interest & {$[.13]$} & {$[.160]$} & [.147] \\
\hline Log income & $\begin{array}{c}0.09 \\
(0.06)\end{array}$ & $\begin{array}{c}0.10 \\
(0.07)\end{array}$ & $\begin{array}{c}0.11 \\
(0.08)\end{array}$ \\
\hline Ideology/Political & & {$[.000]$} & {$[.000]$} \\
\hline Liberal & -- & $\begin{array}{l}-0.41^{* * \star} \\
(0.15)\end{array}$ & $\begin{array}{l}-0.43^{\star \star \star} \\
(0.15)\end{array}$ \\
\hline Conservative & -- & $\begin{array}{l}0.70^{\star \star \star} \\
(0.13)\end{array}$ & $\begin{array}{l}0.60^{\star \star \star *} \\
(0.14)\end{array}$ \\
\hline No thought & -- & $\begin{array}{c}0.03 \\
(0.13) \\
\end{array}$ & $\begin{array}{l}-0.02 \\
(0.14) \\
\end{array}$ \\
\hline Other ideology ${ }^{b}$ & -- & $\begin{array}{l}-0.27 \\
(0.23)\end{array}$ & $\begin{array}{l}-0.45^{\star} \\
(0.24)\end{array}$ \\
\hline Voted & -- & $\begin{array}{l}-0.11 \\
(0.11)\end{array}$ & $\begin{array}{l}-0.06 \\
(0.12)\end{array}$ \\
\hline Taxes too high & -- & $\begin{array}{l}0.57^{* * *} \\
(0.10)\end{array}$ & $\begin{array}{l}0.63^{\star * \star} \\
(0.10)\end{array}$ \\
\hline Taxes too low ${ }^{c}$ & -- & $\begin{array}{l}-0.70^{\star \star} \\
(0.30)\end{array}$ & $\begin{array}{l}-0.78^{* \star} \\
(0.31)\end{array}$ \\
\hline Likes progressivity & -- & $\begin{array}{l}-0.16^{*} \\
(0.09)\end{array}$ & $\begin{array}{l}-0.08 \\
(0.10)\end{array}$ \\
\hline Knowledge & & {$[.005]$} & {$[.006]$} \\
\hline K score & -- & $\begin{array}{l}-0.012^{\star \star \star} \\
(0.003)\end{array}$ & $\begin{array}{l}-0.011^{\star \star *} \\
(0.003)\end{array}$ \\
\hline Tax share & -- & $\begin{array}{l}-0.09 \\
(0.30) \\
\end{array}$ & $\begin{array}{c}0.09 \\
(0.31) \\
\end{array}$ \\
\hline Income tax larger & -- & $\begin{array}{l}-0.12 \\
(0.09)\end{array}$ & $\begin{array}{l}-0.13 \\
(0.10)\end{array}$ \\
\hline Other opinions & & & {$[.000]$} \\
\hline Deficit major problem & -- & $\begin{array}{l}- \\
-- \\
\end{array}$ & $\begin{array}{l}-0.70^{\star \star \star} \\
(0.24)\end{array}$ \\
\hline Deficit minor problem $^{d}$ & -- & $\begin{array}{l}- \\
--\end{array}$ & $\begin{array}{l}-0.24 \\
(0.24)\end{array}$ \\
\hline Demographics $^{a}$ & {$[.004]$} & [.162] & [.239] \\
\hline Years of education & $\begin{array}{l}-.037^{\star *} \\
(.018)\end{array}$ & $\begin{array}{c}0.017 \\
(0.022)\end{array}$ & $\begin{array}{c}0.020 \\
(0.023)\end{array}$ \\
\hline Age & $\begin{array}{l}-.001 \\
(.004) \\
\end{array}$ & $\begin{array}{c}0.0007 \\
(0.0043)\end{array}$ & $\begin{array}{c}0.0031 \\
(0.0045)\end{array}$ \\
\hline Female & $\begin{array}{c}0.017 \\
(0.082)\end{array}$ & $\begin{array}{l}-0.05 \\
(0.09)\end{array}$ & $\begin{array}{c}0.004 \\
(0.098)\end{array}$ \\
\hline Black & $\begin{array}{l}-.35^{\star \star \star} \\
(.12)\end{array}$ & $\begin{array}{l}-0.26^{*} \\
(0.15)\end{array}$ & $\begin{array}{l}-0.22 \\
(0.16)\end{array}$ \\
\hline Other race $e^{e}$ & $\begin{array}{c}.004 \\
(.156) \\
\end{array}$ & $\begin{array}{l}-0.11 \\
(0.18)\end{array}$ & $\begin{array}{l}-0.07 \\
(0.18)\end{array}$ \\
\hline Hispanic & $\begin{array}{c}.20 \\
(.16) \\
\end{array}$ & $\begin{array}{l}0.38^{\star *} \\
(0.18) \\
\end{array}$ & $\begin{array}{l}0.41^{\star \star} \\
(0.18)\end{array}$ \\
\hline Unemployed & $\begin{array}{l}-.15 \\
(.17) \\
\end{array}$ & $\begin{array}{l}-0.002 \\
(0.21) \\
\end{array}$ & $\begin{array}{c}0.09 \\
(0.21) \\
\end{array}$ \\
\hline Retired & $\begin{array}{l}-.004 \\
(.146) \\
\end{array}$ & $\begin{array}{c}0.01 \\
(0.17)\end{array}$ & $\begin{array}{c}-0.04 \\
(0.18)\end{array}$ \\
\hline Homemaker & \begin{tabular}{|c|}
.13 \\
$(.19)$ \\
\end{tabular} & $\begin{array}{c}0.27 \\
(0.22)\end{array}$ & $\begin{array}{c}0.23 \\
(0.23)\end{array}$ \\
\hline Student/other ${ }^{f}$ & $\begin{array}{l}-.17 \\
(.12) \\
\end{array}$ & $\begin{array}{l}-0.13 \\
(0.14)\end{array}$ & $\begin{array}{l}-0.05 \\
(0.15)\end{array}$ \\
\hline Number of observations & 874 & 722 & 697 \\
\hline Log Likelihood & -921 & -680 & -645 \\
\hline Pseudo- $R^{2}$ & .018 & 0.12 & 0.14 \\
\hline
\end{tabular}

See notes to Table 11. 
Table 13

Ordered probit model for view of deficit

Dep. Var.: 3=Serious Problem; 2=Minor Problem; 1=Not a Problem

\begin{tabular}{|c|c|c|c|}
\hline \multirow[t]{2}{*}{ Variable } & \multicolumn{3}{|c|}{$\begin{array}{c}\text { Coefficient } \\
\text { (Standard Error) }\end{array}$} \\
\hline & 1 & 2 & 3 \\
\hline Self-interest & {$[.01]$} & [.16] & {$[.30]$} \\
\hline Log income & $\begin{array}{l}-.17^{\star \star} \\
(.07)\end{array}$ & $\begin{array}{l}-.11 \\
(.08)\end{array}$ & $\begin{array}{l}-.08 \\
(.08) \\
\end{array}$ \\
\hline Ideology/Political & & {$[.00]$} & {$[.00]$} \\
\hline Liberal & -- & $\begin{array}{c}.01 \\
(.16) \\
\end{array}$ & $\begin{array}{l}-.01 \\
(.16) \\
\end{array}$ \\
\hline Conservative & -- & $\begin{array}{c}-.53^{\star * \star} \\
(.13) \\
\end{array}$ & $\begin{array}{c}-.62^{\star \star \star} \\
(.14) \\
\end{array}$ \\
\hline No thought & -- & $\begin{array}{l}-.19 \\
(.15)\end{array}$ & $\begin{array}{l}-.24 \\
(.15) \\
\end{array}$ \\
\hline Other ideology ${ }^{b}$ & -- & $\begin{array}{l}-.46^{\star} \\
(.24)\end{array}$ & $\begin{array}{l}-.51^{\star \star} \\
(.25)\end{array}$ \\
\hline Voted & -- & $\begin{array}{c}.07 \\
(.12) \\
\end{array}$ & $\begin{array}{c}.10 \\
(.13) \\
\end{array}$ \\
\hline Taxes too high & -- & -- & $\begin{array}{l}.20^{\star *} \\
(.10) \\
\end{array}$ \\
\hline Taxes too low ${ }^{c}$ & -- & -- & $\begin{array}{l}-.31 \\
(.26) \\
\end{array}$ \\
\hline Likes progressivity & -- & $\begin{array}{l}.30 \star \star \star \\
(.10) \\
\end{array}$ & $\begin{array}{l}.34^{\star \star \star} \\
(.10) \\
\end{array}$ \\
\hline Knowledge & & [.81] & {$[.84]$} \\
\hline K score & -- & $\begin{array}{c}.001 \\
(.004) \\
\end{array}$ & $\begin{array}{c}.002 \\
(.004) \\
\end{array}$ \\
\hline Tax share & -- & $\begin{array}{c}.003 \\
(.003) \\
\end{array}$ & $\begin{array}{c}.003 \\
(.003) \\
\end{array}$ \\
\hline Income tax larger & -- & $\begin{array}{l}-.02 \\
(.10) \\
\end{array}$ & $\begin{array}{l}-.00 \\
(.10)\end{array}$ \\
\hline Survey Design & {$[.02]$} & [.07] & {$[.08]$} \\
\hline Question Order $^{d}$ & $\begin{array}{l}.20^{\star *} \\
(.09)\end{array}$ & $\begin{array}{l}.18^{\star} \\
(.10) \\
\end{array}$ & $\begin{array}{l}.17^{*} \\
(.10) \\
\end{array}$ \\
\hline Demographics $^{a}$ & {$[.00]$} & {$[.00]$} & {$[.00]$} \\
\hline Years of education & $\begin{array}{l}.03^{\star} \\
(.02) \\
\end{array}$ & $\begin{array}{c}.01 \\
(.02) \\
\end{array}$ & $\begin{array}{c}.01 \\
(.02) \\
\end{array}$ \\
\hline Age & $\begin{array}{l}.009^{\star \star} \\
(.004)\end{array}$ & $\begin{array}{l}.010^{* *} \\
(.005)\end{array}$ & $\begin{array}{l}.010^{\star *} \\
(.005)\end{array}$ \\
\hline Female & $\begin{array}{l}.24^{\star \star \star} \\
(.09)\end{array}$ & $\begin{array}{l}.37^{\star \star \star} \\
(.10)\end{array}$ & $\begin{array}{l}.34^{\star \star \star} \\
(.10)\end{array}$ \\
\hline Black & $\begin{array}{l}.35^{\star \star} \\
(.15) \\
\end{array}$ & $\begin{array}{l}.43^{\star \star} \\
(.18) \\
\end{array}$ & $\begin{array}{l}.40^{\star *} \\
(.18) \\
\end{array}$ \\
\hline Other race ${ }^{e}$ & $\begin{array}{c}.19 \\
(.17) \\
\end{array}$ & $\begin{array}{c}.16 \\
(.19) \\
\end{array}$ & $\begin{array}{c}.15 \\
(.19) \\
\end{array}$ \\
\hline Hispanic & $\begin{array}{c}.16 \\
(.17) \\
\end{array}$ & $\begin{array}{c}.16 \\
(.19) \\
\end{array}$ & $\begin{array}{c}.12 \\
(.19) \\
\end{array}$ \\
\hline Unemployed & $\begin{array}{c}.15 \\
(.20) \\
\end{array}$ & $\begin{array}{c}36 \\
(.24) \\
\end{array}$ & $\begin{array}{c}.33 \\
(.24) \\
\end{array}$ \\
\hline Retired & $\begin{array}{l}-.24 \\
(.16) \\
\end{array}$ & $\begin{array}{l}-.21 \\
(.19) \\
\end{array}$ & $\begin{array}{l}-.20 \\
(.19) \\
\end{array}$ \\
\hline Homemaker & $\begin{array}{l}-.24 \\
(.20) \\
\end{array}$ & $\begin{array}{l}-.40^{\star} \\
(.22)\end{array}$ & $\begin{array}{l}-.26 \\
(.23)\end{array}$ \\
\hline Student/other ${ }^{f}$ & $\begin{array}{c}.10 \\
(.14) \\
\end{array}$ & $\begin{array}{c}.25 \\
(.16) \\
\end{array}$ & $\begin{array}{l}.30 * \\
(.16) \\
\end{array}$ \\
\hline Number of observations & 842 & 716 & 701 \\
\hline Log Likelihood & -661 & -535 & -516 \\
\hline Pseudo-R ${ }^{2}$ & .04 & .09 & .10 \\
\hline
\end{tabular}

See notes to Table 11. 
Table 14

How to reduce the deficit: raise taxes, cut spending or both?

\begin{tabular}{|c|c|c|c|c|c|c|}
\hline \multirow{2}{*}{ Model: } & \multicolumn{3}{|c|}{ Taxes Part of Solution } & \multicolumn{3}{|c|}{ Spending Part of Solution } \\
\hline & 1 & 2 & 3 & 4 & 5 & 6 \\
\hline Self Interest & {$[0.077]$} & {$[0.679]$} & [0.385] & [0.130] & [0.082] & {$[0.112]$} \\
\hline Log Income & $\begin{array}{c}-0.022 \\
(0.073)\end{array}$ & $\begin{array}{c}-0.031 \\
(0.074)\end{array}$ & $\begin{array}{c}-0.073 \\
(0.085)\end{array}$ & $\begin{array}{c}0.165 \\
(0.109)\end{array}$ & $\begin{array}{c}0.200 * \\
(0.115)\end{array}$ & $\begin{array}{c}0.220 \\
(0.138)\end{array}$ \\
\hline Ideology/Political & --- & [0.278] & {$[0.584]$} & --- & [0.000] & [0.001] \\
\hline Liberal & --- & $\begin{array}{c}-0.027 \\
(0.158) \\
\end{array}$ & $\begin{array}{r}-0.072 \\
(0.174) \\
\end{array}$ & --- & $\begin{array}{c}-0.612^{\star * *} \\
(0.224) \\
\end{array}$ & $\begin{array}{c}-0.685^{\star * \star} \\
(0.257)\end{array}$ \\
\hline Conservative & --- & $\begin{array}{c}-0.197 \\
(0.138)\end{array}$ & $\begin{array}{c}-0.104 \\
(0.151)\end{array}$ & --- & $\begin{array}{c}0.237 \\
(0.239)\end{array}$ & $\begin{array}{c}0.061 \\
(0.269)\end{array}$ \\
\hline No thought & --- & $\begin{array}{c}-0.278 \\
(0.145)\end{array}$ & $\begin{array}{c}-0.217 \\
(0.160)\end{array}$ & --- & $\begin{array}{c}0.247 \\
(0.258)\end{array}$ & $\begin{array}{c}0.140 \\
(0.299)\end{array}$ \\
\hline Other ideology & --- & $\begin{array}{c}-0.408^{\star \star} \\
(0.264)\end{array}$ & $\begin{array}{l}-0.435 \\
(0.282)\end{array}$ & -- & $\begin{array}{l}-0.624^{*} \\
(0.324)\end{array}$ & $\begin{array}{c}-0.818^{\star \star} \\
(0.368)\end{array}$ \\
\hline Voted & --- & $\begin{array}{c}0.022 \\
(0.118) \\
\end{array}$ & $\begin{array}{c}0.050 \\
(0.133) \\
\end{array}$ & --- & $\begin{array}{l}-0.347^{*} \\
(0.213)\end{array}$ & $\begin{array}{l}-0.501^{*} \\
(0.258)\end{array}$ \\
\hline Knowledge & --- & [0.095] & {$[0.007]$} & --- & [0.316] & [0.372] \\
\hline K score & $\overline{---}$ & $\begin{array}{c}-0.005^{\star} \\
(0.003)\end{array}$ & $\begin{array}{l}-0.008^{*} \\
(0.004)\end{array}$ & --- & $\begin{array}{l}-0.005 \\
(0.005)\end{array}$ & $\begin{array}{l}-0.005 \\
(0.007)\end{array}$ \\
\hline Tax Share & -- & -- & $\begin{array}{c}0.000 \\
(0.004)\end{array}$ & --- & --- & $\begin{array}{c}0.008 \\
(0.007)\end{array}$ \\
\hline Income tax larger & -- & --- & $\begin{array}{c}-0.340^{\star \star \star} \\
(0.108)\end{array}$ & --- & --- & $\begin{array}{c}-0.097 \\
(0.184)\end{array}$ \\
\hline Other Opinions & --- & & {$[0.000]$} & --- & --- & {$[0.002]$} \\
\hline Likes Progressivity & --- & --- & $\begin{array}{c}0.063 \\
(0.110) \\
\end{array}$ & --- & --- & $\begin{array}{c}-0.004 \\
(0.196) \\
\end{array}$ \\
\hline Taxes too high & --- & --- & $\begin{array}{c}-0.630 \star \star \star \\
(0.116)\end{array}$ & --- & --- & $\begin{array}{l}0.521^{\star \star \star} \\
(0.191)\end{array}$ \\
\hline Taxes too low & --- & $\begin{array}{ll}-- \\
-1\end{array}$ & $\begin{array}{c}0.525 \\
(0.330) \\
\end{array}$ & --- & $\begin{array}{ll}-- \\
\end{array}$ & $\begin{array}{c}-0.668^{\star \star} \\
(0.338) \\
\end{array}$ \\
\hline Demographics & {$[0.005]$} & {$[0.026]$} & {$[0.062]$} & [0.135] & {$[0.886]$} & [0.841] \\
\hline Years of Education & $\begin{array}{l}-0.012 \\
(0.021) \\
\end{array}$ & $\begin{array}{c}-0.028 \\
(0.023) \\
\end{array}$ & $\begin{array}{l}-0.049 * \\
(0.026)\end{array}$ & $\begin{array}{c}-0.098^{* * *} \\
(0.032)\end{array}$ & $\begin{array}{c}-0.047 \\
(0.037)\end{array}$ & $\begin{array}{c}-0.013 \\
(0.043) \\
\end{array}$ \\
\hline Age & $\begin{array}{c}-0.011^{\star \star} \\
(0.004)\end{array}$ & $\begin{array}{c}-0.010 \text { ** } \\
(0.004)\end{array}$ & $\begin{array}{c}-0.010^{\star \star} \\
(0.005)\end{array}$ & $\begin{array}{c}-0.006 \\
(0.007)\end{array}$ & $\begin{array}{c}-0.003 \\
(0.007)\end{array}$ & $\begin{array}{c}0.006 \\
(0.009)\end{array}$ \\
\hline Female & $\begin{array}{l}-0.059 \\
(0.097) \\
\end{array}$ & $\begin{array}{c}-0.096 \\
(0.099) \\
\end{array}$ & $\begin{array}{l}-0.090 \\
(0.109)\end{array}$ & $\begin{array}{c}0.076 \\
(0.152)\end{array}$ & $\begin{array}{c}0.048 \\
(0.164)\end{array}$ & $\begin{array}{c}0.130 \\
(0.186)\end{array}$ \\
\hline Black & $\begin{array}{c}-0.143 \\
(0.153)\end{array}$ & $\begin{array}{c}-0.118 \\
(0.159)\end{array}$ & $\begin{array}{c}-0.167 \\
(0.184)\end{array}$ & $\begin{array}{l}-0.163 \\
(0.227)\end{array}$ & $\begin{array}{l}-0.061 \\
(0.249)\end{array}$ & $\begin{array}{c}-0.237 \\
(0.297)\end{array}$ \\
\hline Other race & $\begin{array}{c}0.167 \\
(0.186) \\
\end{array}$ & $\begin{array}{c}0.164 \\
(0.188) \\
\end{array}$ & $\begin{array}{c}0.108 \\
(0.209) \\
\end{array}$ & $\begin{array}{c}0.023 \\
(0.280) \\
\end{array}$ & $\begin{array}{c}-0.111 \\
(0.295)\end{array}$ & $\begin{array}{c}-0.227 \\
(0.323)\end{array}$ \\
\hline Hispanic & $\begin{array}{c}0.093 \\
(0.188) \\
\end{array}$ & $\begin{array}{c}0.041 \\
(0.190)\end{array}$ & $\begin{array}{l}-0.079 \\
(0.213)\end{array}$ & $\begin{array}{l}-0.091 \\
(0.275)\end{array}$ & $\begin{array}{c}0.002 \\
(0.297)\end{array}$ & $\begin{array}{c}-0.077 \\
(0.312)\end{array}$ \\
\hline Unemployed & $\begin{array}{c}0.036 \\
(0.211)\end{array}$ & $\begin{array}{c}0.012 \\
(0.216)\end{array}$ & $\begin{array}{c}-0.344 \\
(0.245)\end{array}$ & $\begin{array}{c}-0.278 \\
(0.299)\end{array}$ & $\begin{array}{c}-0.309 \\
(0.321)\end{array}$ & $\begin{array}{l}-0.449 \\
(0.349)\end{array}$ \\
\hline Retired & $\begin{array}{c}0.256 \\
(0.176) \\
\end{array}$ & $\begin{array}{c}0.246 \\
(0.180) \\
\end{array}$ & $\begin{array}{c}0.092 \\
(0.206) \\
\end{array}$ & $\begin{array}{c}0.204 \\
(0.282) \\
\end{array}$ & $\begin{array}{c}0.091 \\
(0.296) \\
\end{array}$ & $\begin{array}{c}0.119 \\
(0.353) \\
\end{array}$ \\
\hline Homemaker & $\begin{array}{c}0.155 \\
(0.225) \\
\end{array}$ & $\begin{array}{c}0.172 \\
(0.226) \\
\end{array}$ & $\begin{array}{c}0.090 \\
(0.255)\end{array}$ & $\begin{array}{l}-0.110 \\
(0.359)\end{array}$ & $\begin{array}{l}-0.143 \\
(0.378)\end{array}$ & $\begin{array}{l}-0.171 \\
(0.444)\end{array}$ \\
\hline Married & $\begin{array}{l}-0.117 \\
(0.136) \\
\end{array}$ & $\begin{array}{l}-0.092 \\
(0.138) \\
\end{array}$ & $\begin{array}{l}-0.210 \\
(0.156)\end{array}$ & $\begin{array}{c}0.248 \\
(0.196) \\
\end{array}$ & $\begin{array}{c}0.229 \\
(0.211) \\
\end{array}$ & $\begin{array}{c}0.226 \\
(0.239) \\
\end{array}$ \\
\hline Student/other & $\begin{array}{l}0.317^{\star *} \\
(0.148)\end{array}$ & $\begin{array}{l}0.300 * \star \\
(0.152)\end{array}$ & $\begin{array}{c}0.163 \\
(0.174) \\
\end{array}$ & $\begin{array}{l}-0.239 \\
(0.208)\end{array}$ & $\begin{array}{l}-0.255 \\
(0.223)\end{array}$ & $\begin{array}{l}-0.041 \\
(0.268)\end{array}$ \\
\hline $\begin{array}{l}\text { Number of observations } \\
\text { Pseudo- } R^{2}\end{array}$ & $\begin{array}{c}780 \\
0.031 \\
\end{array}$ & $\begin{array}{c}771 \\
0.038 \\
\end{array}$ & $\begin{array}{c}662 \\
0.096 \\
\end{array}$ & $\begin{array}{c}780 \\
0.056 \\
\end{array}$ & $\begin{array}{c}771 \\
0.135 \\
\end{array}$ & $\begin{array}{c}662 \\
0.199 \\
\end{array}$ \\
\hline
\end{tabular}

Notes: See notes to Table 11. Also controls for order of deficit.

Probit estimates with standard errors in parentheses. 
Table 15

Probit model for supporting minimum wage increase

\begin{tabular}{|c|c|c|c|}
\hline \multirow[t]{2}{*}{ Variable } & \multicolumn{3}{|c|}{$\begin{array}{c}\text { Coefficient } \\
\text { (Standard Error) }\end{array}$} \\
\hline & 1 & 2 & 3 \\
\hline Self-interest & [.03] & {$[.08]$} & {$[.011]$} \\
\hline Log income & $\begin{array}{l}-.22^{\star \star \star} \\
(.08)\end{array}$ & $\begin{array}{l}-.19^{\star \star} \\
(.09)\end{array}$ & $\begin{array}{l}-.28^{\star \star \star} \\
(.10)\end{array}$ \\
\hline Ideology/Political & & {$[.000]$} & {$[.002]$} \\
\hline Liberal & -- & $\begin{array}{l}.12 \\
(.19)\end{array}$ & $\begin{array}{l}.19 \\
(.22)\end{array}$ \\
\hline Conservative & -- & $\begin{array}{l}-.48^{\star \star \star} \\
(.15)\end{array}$ & $\begin{array}{l}-.39^{\star \star} \\
(.17)\end{array}$ \\
\hline No thought & -- & $\begin{array}{l}.10 \\
(.17)\end{array}$ & $\begin{array}{l}.10 \\
(.20)\end{array}$ \\
\hline \multirow[t]{2}{*}{ Other ideology ${ }^{b}$} & -- & $\begin{array}{l}-.09 \\
(.29)\end{array}$ & $\begin{array}{l}-.06 \\
(.32)\end{array}$ \\
\hline & -- & $\begin{array}{l}-.03 \\
(.14)\end{array}$ & $\begin{array}{l}-.24 \\
(.17)\end{array}$ \\
\hline Knowledge & & {$[.34]$} & {$[.006]$} \\
\hline \multirow[b]{2}{*}{ Value of Min. Wage } & -- & $\begin{array}{c}.004 \\
(.004)\end{array}$ & $\begin{array}{l}-.001 \\
(.004)\end{array}$ \\
\hline & -- & $\begin{array}{l}-- \\
--\end{array}$ & $\begin{array}{l}-.18^{\star \star \star} \\
(.06)\end{array}$ \\
\hline Other opinions & & & {$[.002]$} \\
\hline \multirow{2}{*}{$\begin{array}{l}\text { A lot lose jobs } \\
\text { Some lose jobs }\end{array}$} & -- & -- & $\begin{array}{l}-1.73^{\star \star \star} \\
(.25)\end{array}$ \\
\hline & -- & -- & $\begin{array}{l}-.95^{\star * *} \\
(.13)\end{array}$ \\
\hline Demographics $^{a}$ & {$[.000]$} & {$[.000]$} & {$[.000]$} \\
\hline Years of education & $\begin{array}{l}-.08^{\star \star \star} \\
(.02)\end{array}$ & $\begin{array}{l}-.09 \star \star \star \\
(.03)\end{array}$ & $\begin{array}{l}-.07^{* *} \\
(.03)\end{array}$ \\
\hline Age & $\begin{array}{l}.002 \\
(.005)\end{array}$ & $\begin{array}{l}.001 \\
(.005)\end{array}$ & $\begin{array}{l}-.008 \\
(.006)\end{array}$ \\
\hline Female & $\begin{array}{l}.42^{\star \star \star} \\
(.11)\end{array}$ & $\begin{array}{l}.39 * * \star \\
(.12)\end{array}$ & $\begin{array}{l}.47^{\star \star \star} \\
(.13)\end{array}$ \\
\hline Black & $\begin{array}{l}1.18^{\star \star \star} \\
(.29)\end{array}$ & $\begin{array}{l}1.05^{\star \star \star} \\
(.30)\end{array}$ & $\begin{array}{l}1.13^{\star \star} \\
(.46)\end{array}$ \\
\hline Other race ${ }^{e}$ & $\begin{array}{l}.40^{*} \\
(.22)\end{array}$ & $\begin{array}{l}.38 \\
(.23) \\
\end{array}$ & $\begin{array}{l}.34 \\
(.26)\end{array}$ \\
\hline Hispanic & $\begin{array}{l}.23 \\
(.23)\end{array}$ & $\begin{array}{l}.17 \\
(.24)\end{array}$ & $\begin{array}{l}.34 \\
(.27)\end{array}$ \\
\hline Unemployed & $\begin{array}{l}-.04 \\
(.26)\end{array}$ & $\begin{array}{l}-.14 \\
(.26)\end{array}$ & $\begin{array}{l}.41 \\
(.31)\end{array}$ \\
\hline Retired & $\begin{array}{r}-.17 \\
(.20)\end{array}$ & $\begin{array}{l}-.20 \\
(.20)\end{array}$ & $\begin{array}{l}-.02 \\
(.23)\end{array}$ \\
\hline Homemaker & $\begin{array}{l}.09 \\
(.26)\end{array}$ & $\begin{array}{l}.10 \\
(.26)\end{array}$ & $\begin{array}{l}.16 \\
(.30)\end{array}$ \\
\hline Student/other ${ }^{f}$ & $\begin{array}{l}-.14 \\
(.18) \\
\end{array}$ & $\begin{array}{l}-0.14 \\
(0.18)\end{array}$ & $\begin{array}{l}-.37^{*} \\
(.21) \\
\end{array}$ \\
\hline Number of observations & 838 & 823 & 761 \\
\hline Log Likelihood & -380 & -364 & -284 \\
\hline Pseudo- $R^{2}$ & .13 & .16 & .29 \\
\hline
\end{tabular}

See notes to Table 11. 
Table 16

Ordered probit model for favoring personal investment accounts

\begin{tabular}{|c|c|c|c|}
\hline \multirow[b]{2}{*}{ Variable } & \multicolumn{3}{|c|}{$\begin{array}{c}\text { Coefficient } \\
\text { (Standard Error) }\end{array}$} \\
\hline & 1 & 2 & 3 \\
\hline Self-interest & {$[.06]$} & {$[.004]$} & {$[.003]$} \\
\hline \multirow[t]{2}{*}{ Log income } & $.15^{\star \star}$ & .11 & .11 \\
\hline & $(.06)$ & $(.07)$ & $(.07)$ \\
\hline \multirow[t]{2}{*}{ Age } & .004 & -.008 & $-.009^{*}$ \\
\hline & $(.004)$ & $(.005)$ & $(.005)$ \\
\hline \multirow[t]{2}{*}{ Both Parents Alive } & .18 & .05 & -.04 \\
\hline & $(.12)$ & (.13) & (.13) \\
\hline \multirow[t]{2}{*}{ Mother Alive } & .06 & .03 & .05 \\
\hline & $(.14)$ & (.15) & (.15) \\
\hline \multirow[t]{2}{*}{ Father Alive } & .01 & -.15 & -.14 \\
\hline & $(.20)$ & $(.24)$ & $(.24)$ \\
\hline \multirow[t]{2}{*}{ SS Major Income Source } & $-.22^{*}$ & $-.40^{\star \star \star}$ & $-.36^{\star \star \star}$ \\
\hline & $(.12)$ & $(.13)$ & $(.14)$ \\
\hline \multirow[t]{2}{*}{ SS Minor Income Source } & $-.17^{*}$ & $-.31^{\star \star \star}$ & $-.30^{\star \star \star}$ \\
\hline & $(.10)$ & $(.11)$ & $(.11)$ \\
\hline Ideology/Political & & {$[.000]$} & {$[.000]$} \\
\hline \multirow[t]{2}{*}{ Liberal } & -- & $-.38^{\star \star \star}$ & $-.40^{\star \star \star}$ \\
\hline & & $(.15)$ & $(.15)$ \\
\hline \multirow{2}{*}{ Conservative } & -- & $.87^{\star \star \star}$ & $.87^{\star \star \star}$ \\
\hline & & $(.13)$ & (.13) \\
\hline \multirow[t]{2}{*}{ No thought } & -- & $.31^{\star \star}$ & $.34^{\star \star}$ \\
\hline & & $(.14)$ & (.14) \\
\hline \multirow[t]{2}{*}{ Other ideology ${ }^{b}$} & -- & -.12 & -.18 \\
\hline & & $(.23)$ & $(.24)$ \\
\hline \multirow[t]{2}{*}{ Voted } & -- & .04 & .02 \\
\hline & & (.11) & (.11) \\
\hline Knowledge & & {$[.35]$} & [.41] \\
\hline \multirow[t]{2}{*}{ K score } & -- & .003 & .002 \\
\hline & & $(.003)$ & $(.003)$ \\
\hline \multirow[t]{2}{*}{ Monthly SS Benefit } & -- & .09 & .10 \\
\hline & & $(.09)$ & (.09) \\
\hline Other Knowledge & & & {$[.36]$} \\
\hline \multirow[t]{2}{*}{ Aware of Bush Proposal } & -- & -- & .13 \\
\hline & & -- & (.10) \\
\hline Aware of Soc Sec Defecit & -- & -- & .05 \\
\hline & & -- & (.11) \\
\hline Demographics $^{a}$ & [.19] & {$[.22]$} & {$[.38]$} \\
\hline Years of education & .03 & $.05^{\star \star}$ & $.05^{\star \star}$ \\
\hline & $(.02)$ & $(.02)$ & $(.02)$ \\
\hline Female & $-.26^{\star \star \star}$ & -.15 & -.11 \\
\hline & $(.08)$ & $(.09)$ & $(.10)$ \\
\hline Black & -.16 & -.07 & -.06 \\
\hline & (.13) & (.16) & (.16) \\
\hline Other race ${ }^{e}$ & -.04 & -.24 & -.25 \\
\hline & (.15) & $(.17)$ & $(.17)$ \\
\hline Hispanic & .15 & $.34^{\star \star}$ & $.34^{\star \star}$ \\
\hline & $(.15)$ & $(.17)$ & $(.17)$ \\
\hline Unemployed & -.05 & .07 & .03 \\
\hline & $(.18)$ & (.19) & (.19) \\
\hline Retired & -.10 & -.03 & $\begin{array}{l}.02 \\
\end{array}$ \\
\hline & (.15) & (.17) & $(.17)$ \\
\hline Homemaker & .18 & .14 & .12 \\
\hline & (.18) & $(.20)$ & $(.20)$ \\
\hline Student/other & -.06 & -.04 & -.06 \\
\hline & $(.13)$ & (.15) & (.15) \\
\hline Number of observations & 862 & 736 & 731 \\
\hline Log Likelihood & -883 & -713 & -706 \\
\hline Pseudo- $R^{2}$ & .03 & .10 & .10 \\
\hline
\end{tabular}

See notes to Table 11 . 
Table 17

How Should the Social Security Deficit Be Reduced?

\begin{tabular}{|c|c|c|c|c|c|c|}
\hline \multirow{2}{*}{ Variable } & \multicolumn{3}{|c|}{ Raising Taxes Part of Solution } & \multicolumn{3}{|c|}{ Cutting Benefits Part of Solution } \\
\hline & 1 & 2 & 3 & 4 & 5 & \\
\hline Self Interest & [0.015] & {$[0.563]$} & [0.566] & [0.005] & [0.222] & [0.282] \\
\hline Log income & $\begin{array}{l}-0.088 \\
(0.078)\end{array}$ & $\begin{array}{c}-0.143 \\
(0.088)\end{array}$ & $\begin{array}{c}-0.121 \\
(0.090)\end{array}$ & $\begin{array}{c}0.099 \\
(0.073)\end{array}$ & $\begin{array}{c}0.064 \\
(0.082)\end{array}$ & $\begin{array}{c}0.072 \\
(0.083)\end{array}$ \\
\hline Age & $\begin{array}{c}-0.007 \\
(0.005) \\
\end{array}$ & $\begin{array}{c}-0.003 \\
(0.006) \\
\end{array}$ & $\begin{array}{c}-0.002 \\
(0.006) \\
\end{array}$ & $\begin{array}{l}-0.009^{\star} \\
(0.005)\end{array}$ & $\begin{array}{l}-0.007 \\
(0.006)\end{array}$ & $\begin{array}{l}-0.007 \\
(0.006)\end{array}$ \\
\hline Both parents alive & $\begin{array}{c}0.093 \\
(0.153) \\
\end{array}$ & $\begin{array}{c}0.071 \\
(0.165) \\
\end{array}$ & $\begin{array}{c}0.107 \\
(0.170) \\
\end{array}$ & $\begin{array}{c}0.229 \\
(0.145) \\
\end{array}$ & $\begin{array}{c}0.140 \\
(0.156) \\
\end{array}$ & $\begin{array}{c}0.108 \\
(0.159) \\
\end{array}$ \\
\hline Father alive & $\begin{array}{c}-0.341 \\
(0.243) \\
\end{array}$ & $\begin{array}{c}-0.027 \\
(0.282) \\
\end{array}$ & $\begin{array}{c}0.088 \\
(0.292) \\
\end{array}$ & $\begin{array}{l}-0.350 \\
(0.251) \\
\end{array}$ & $\begin{array}{l}-0.315 \\
(0.276) \\
\end{array}$ & $\begin{array}{c}-0.371 \\
(0.280)\end{array}$ \\
\hline Mother alive & $\begin{array}{c}0.167 \\
(0.176)\end{array}$ & $\begin{array}{c}0.117 \\
(0.182)\end{array}$ & $\begin{array}{c}0.125 \\
(0.184)\end{array}$ & $\begin{array}{c}0.285^{\star} \\
(0.166)\end{array}$ & $\begin{array}{c}0.208 \\
(0.171)\end{array}$ & $\begin{array}{c}0.162 \\
(0.173)\end{array}$ \\
\hline SS major income source & $\begin{array}{c}0.477^{\star \star \star} \\
(0.147)\end{array}$ & $\begin{array}{c}0.268 \\
(0.171)\end{array}$ & $\begin{array}{c}0.322^{\star} \\
(0.176)\end{array}$ & $\begin{array}{c}0.100 \\
(0.137)\end{array}$ & $\begin{array}{l}-0.074 \\
(0.159) \\
\end{array}$ & $\begin{array}{c}-0.063 \\
(0.162)\end{array}$ \\
\hline SS minor income source & $\begin{array}{c}0.214^{\star} \\
(0.119) \\
\end{array}$ & $\begin{array}{c}0.158 \\
(0.133) \\
\end{array}$ & $\begin{array}{c}0.166 \\
(0.135) \\
\end{array}$ & $\begin{array}{c}-0.071 \\
(0.115) \\
\end{array}$ & $\begin{array}{l}-0.086 \\
(0.127) \\
\end{array}$ & $\begin{array}{l}-0.064 \\
(0.128) \\
\end{array}$ \\
\hline Ideology/Political & --- & {$[0.122]$} & {$[0.196]$} & --- & [0.485] & [0.465] \\
\hline Liberal & --- & $\begin{array}{c}0.122 \\
(0.183)\end{array}$ & $\begin{array}{c}0.105 \\
(0.187)\end{array}$ & --- & $\begin{array}{c}0.188 \\
(0.173)\end{array}$ & $\begin{array}{c}0.207 \\
(0.175)\end{array}$ \\
\hline Conservative & --- & $\begin{array}{c}-0.106 \\
(0.155) \\
\end{array}$ & $\begin{array}{c}-0.115 \\
(0.159) \\
\end{array}$ & --- & $\begin{array}{c}0.142 \\
(0.149) \\
\end{array}$ & $\begin{array}{c}0.128 \\
(0.152) \\
\end{array}$ \\
\hline No thought & --- & $\begin{array}{c}-0.001 \\
(0.175) \\
\end{array}$ & $\begin{array}{c}0.001 \\
(0.177) \\
\end{array}$ & --- & $\begin{array}{c}0.293 \\
(0.163) \\
\end{array}$ & $\begin{array}{c}0.296^{\star} \\
(0.164) \\
\end{array}$ \\
\hline \multirow[t]{2}{*}{ Other } & --- & $\begin{array}{c}-0.663^{\star \star} \\
(0.281)\end{array}$ & $\begin{array}{c}-0.652^{\star \star} \\
(0.294)\end{array}$ & --- & $\begin{array}{c}-0.112 \\
(0.290) \\
\end{array}$ & $\begin{array}{c}-0.102 \\
(0.299)\end{array}$ \\
\hline & --- & $\begin{array}{c}0.121 \\
(0.140) \\
\end{array}$ & $\begin{array}{c}0.102 \\
(0.142) \\
\end{array}$ & --- & $\begin{array}{c}0.090 \\
(0.131) \\
\end{array}$ & $\begin{array}{c}0.104 \\
(0.132) \\
\end{array}$ \\
\hline Knowledge & --- & {$[0.066]$} & {$[0.054]$} & --- & [0.100] & [0.093] \\
\hline K score & --- & $\begin{array}{c}-0.008^{\star \star} \\
(0.004)\end{array}$ & $\begin{array}{c}-0.009 * \star \\
(0.004)\end{array}$ & --- & $\begin{array}{c}0.001 \\
(0.004) \\
\end{array}$ & $\begin{array}{c}0.001 \\
(0.004)\end{array}$ \\
\hline Monthly benefits (/100) & --- & $\begin{array}{c}0.009 \\
(0.010)\end{array}$ & $\begin{array}{c}0.007 \\
(0.011) \\
\end{array}$ & --- & $\begin{array}{l}0.017^{*} \\
(0.010)\end{array}$ & $\begin{array}{c}0.017^{\star} \\
(0.010)\end{array}$ \\
\hline \multirow{2}{*}{$\begin{array}{l}\text { Aware of Bush proposal } \\
\text { Aware of pending Social } \\
\text { Security deficit }\end{array}$} & --- & $\begin{array}{c}-0.204 \\
(0.130)\end{array}$ & $\begin{array}{c}-0.198 \\
(0.132)\end{array}$ & --- & $\begin{array}{l}-0.252^{\star \star} \\
(0.122)\end{array}$ & $\begin{array}{c}-0.265^{\star \star} \\
(0.123)\end{array}$ \\
\hline & --- & $\begin{array}{c}0.210 \\
(0.148) \\
\end{array}$ & $\begin{array}{c}0.233 \\
(0.149) \\
\end{array}$ & --- & $\begin{array}{l}-0.064 \\
(0.136) \\
\end{array}$ & $\begin{array}{c}-0.057 \\
(0.137) \\
\end{array}$ \\
\hline Other Opinions & --- & --- & {$[0.100]$} & --- & --- & [0.278] \\
\hline \multirow[t]{2}{*}{ Taxes too high } & --- & --- & $\begin{array}{c}-0.252^{\star \star} \\
(0.118)\end{array}$ & --- & --- & $\begin{array}{c}0.171 \\
(0.110)\end{array}$ \\
\hline & --- & --- & $\begin{array}{c}-0.149 \\
(0.288) \\
\end{array}$ & --- & --- & $\begin{array}{c}0.191 \\
(0.277) \\
\end{array}$ \\
\hline Demographics & {$[0.029]$} & [0.318] & [0.268] & [0.005] & [0.021] & [0.049] \\
\hline Years of education & $\begin{array}{c}0.036 \\
(0.023) \\
\end{array}$ & $\begin{array}{c}0.007 \\
(0.027) \\
\end{array}$ & $\begin{array}{c}0.003 \\
(0.028) \\
\end{array}$ & $\begin{array}{c}-0.062^{\star \star *} \\
(0.022)\end{array}$ & $\begin{array}{l}-0.041 \\
(0.027) \\
\end{array}$ & $\begin{array}{c}-0.035 \\
(0.027) \\
\end{array}$ \\
\hline Female & $\begin{array}{c}0.269 * \star \star \\
(0.105)\end{array}$ & $\begin{array}{c}0.163 \\
(0.118) \\
\end{array}$ & $\begin{array}{c}0.155 \\
(0.120) \\
\end{array}$ & $\begin{array}{c}-0.238^{\star *} \\
(0.099)\end{array}$ & $\begin{array}{c}-0.368^{\star \star *} \\
(0.113)\end{array}$ & $\begin{array}{c}-0.369 * * * \\
(0.115)\end{array}$ \\
\hline Black & $\begin{array}{c}0.157 \\
(0.169) \\
\end{array}$ & $\begin{array}{c}0.168 \\
(0.211) \\
\end{array}$ & $\begin{array}{c}0.182 \\
(0.212) \\
\end{array}$ & $\begin{array}{c}0.295^{\star} \\
(0.153) \\
\end{array}$ & $\begin{array}{c}0.173 \\
(0.187) \\
\end{array}$ & $\begin{array}{c}0.148 \\
(0.188) \\
\end{array}$ \\
\hline Other race & $\begin{array}{c}-0.038 \\
(0.194) \\
\end{array}$ & $\begin{array}{c}0.006 \\
(0.211) \\
\end{array}$ & $\begin{array}{c}0.091 \\
(0.220) \\
\end{array}$ & $\begin{array}{c}-0.239 \\
(0.185) \\
\end{array}$ & $\begin{array}{l}-0.267 \\
(0.200) \\
\end{array}$ & $\begin{array}{c}-0.248 \\
(0.203) \\
\end{array}$ \\
\hline Hispanic & $\begin{array}{l}0.352^{\star} \\
(0.208) \\
\end{array}$ & $\begin{array}{c}0.277 \\
(0.219) \\
\end{array}$ & $\begin{array}{c}0.200 \\
(0.223) \\
\end{array}$ & $\begin{array}{l}0.307^{*} \\
(0.187) \\
\end{array}$ & $\begin{array}{l}0.367^{*} \\
(0.197) \\
\end{array}$ & $\begin{array}{l}0.360^{*} \\
(0.198) \\
\end{array}$ \\
\hline Unemployed & $\begin{array}{l}0.602^{\star \star} \\
(0.280)\end{array}$ & $\begin{array}{l}0.795^{\star \star} \\
(0.318)\end{array}$ & $\begin{array}{l}0.821^{\star *} \\
(0.323)\end{array}$ & $\begin{array}{l}-0.077 \\
(0.216) \\
\end{array}$ & $\begin{array}{l}-0.009 \\
(0.226) \\
\end{array}$ & $\begin{array}{l}-0.023 \\
(0.227) \\
\end{array}$ \\
\hline Retired & $\begin{array}{l}-0.289 \\
(0.186) \\
\end{array}$ & $\begin{array}{l}-0.100 \\
(0.206) \\
\end{array}$ & $\begin{array}{l}-0.167 \\
(0.210) \\
\end{array}$ & $\begin{array}{l}-0.167 \\
(0.186) \\
\end{array}$ & $\begin{array}{l}-0.046 \\
(0.201) \\
\end{array}$ & $\begin{array}{l}-0.037 \\
(0.204)\end{array}$ \\
\hline Homemaker & $\begin{array}{c}-0.197 \\
(0.229)\end{array}$ & $\begin{array}{c}-0.247 \\
(0.240)\end{array}$ & $\begin{array}{c}-0.321 \\
(0.244)\end{array}$ & $\begin{array}{l}-0.079 \\
(0.221)\end{array}$ & $\begin{array}{l}-0.117 \\
(0.235)\end{array}$ & $\begin{array}{c}-0.079 \\
(0.239)\end{array}$ \\
\hline Student/Other & $\begin{array}{c}-0.075 \\
(0.160) \\
\end{array}$ & $\begin{array}{c}-0.074 \\
(0.181) \\
\end{array}$ & $\begin{array}{c}-0.089 \\
(0.185) \\
\end{array}$ & $\begin{array}{c}-0.345^{\star \star} \\
(0.151)\end{array}$ & $\begin{array}{l}-0.375^{\star *} \\
(0.174)\end{array}$ & $\begin{array}{c}-0.342^{\star *} \\
(0.176)\end{array}$ \\
\hline $\begin{array}{l}\text { Number of observ } \\
\text { Pseudo- } R^{2}\end{array}$ & $\begin{array}{c}793 \\
0.063\end{array}$ & $\begin{array}{c}676 \\
0.069\end{array}$ & $\begin{array}{c}664 \\
0.075\end{array}$ & $\begin{array}{c}793 \\
0.060\end{array}$ & $\begin{array}{c}676 \\
0.065\end{array}$ & $\begin{array}{c}664 \\
0.065\end{array}$ \\
\hline
\end{tabular}

Notes: See notes to Table 11. Probit estimates with standard errors in parentheses. Equation also controls for married, cohabitation, widowed, divorced or separated, and order of deficit questions. 
Table 18

Probit model for favoring universal health insurance

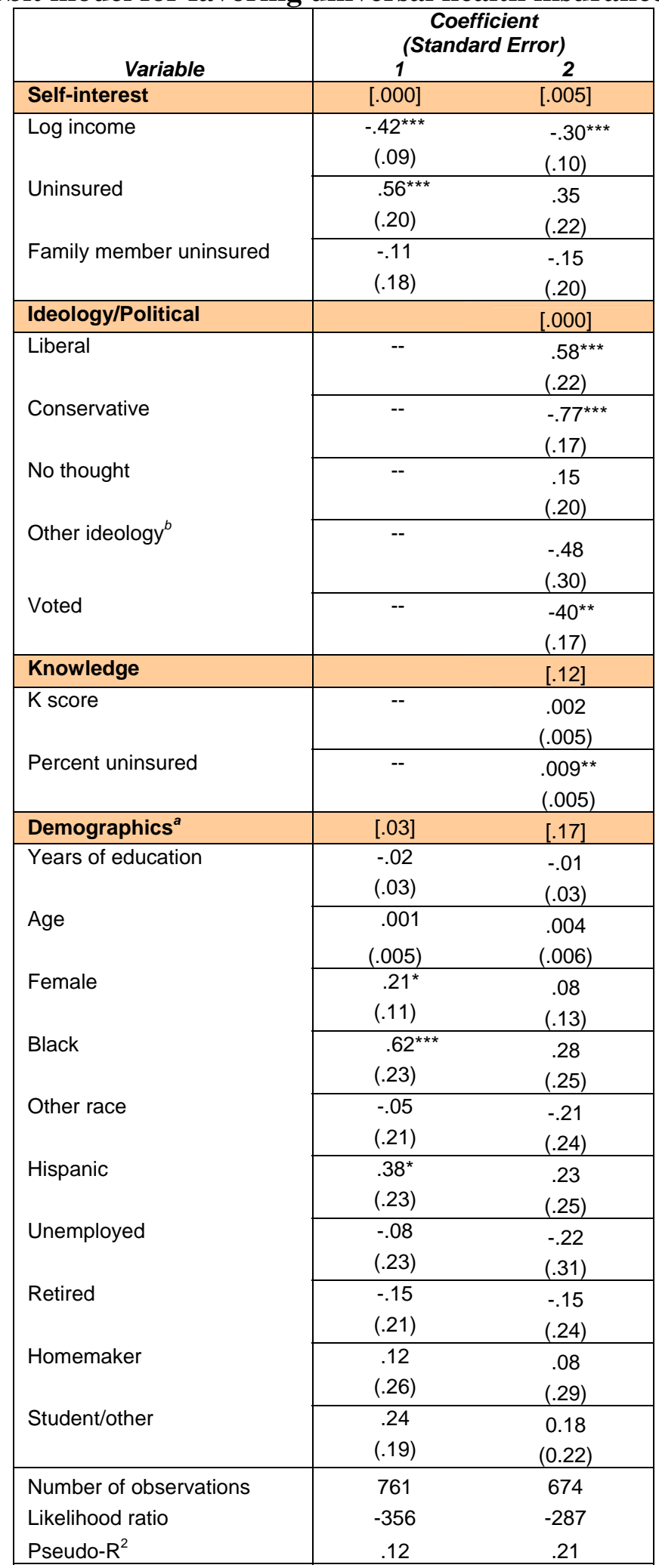

See notes to Table 11. 
Table 19

Support for Prescription Drug Insurance in Medicare

\begin{tabular}{|c|c|c|c|}
\hline Variable & 1 & 2 & 3 \\
\hline Self-Interest & [0.524] & [0.453] & [0.240] \\
\hline Log income & $\begin{array}{c}0.100 \\
(0.119)\end{array}$ & $\begin{array}{c}0.100 \\
(0.119)\end{array}$ & $\begin{array}{c}0.107 \\
(0.128)\end{array}$ \\
\hline Age & $\begin{array}{l}-0.008 \\
(0.007)\end{array}$ & $\begin{array}{l}-0.007 \\
(0.008)\end{array}$ & $\begin{array}{l}-0.016^{*} \\
(0.008)\end{array}$ \\
\hline Both parents alive & $\begin{array}{l}-0.010 \\
(0.220)\end{array}$ & $\begin{array}{c}0.022 \\
(0.221)\end{array}$ & $\begin{array}{l}-0.111 \\
(0.231)\end{array}$ \\
\hline Father alive & $\begin{array}{c}0.297 \\
(0.470)\end{array}$ & $\begin{array}{c}0.306 \\
(0.465)\end{array}$ & $\begin{array}{c}0.083 \\
(0.480)\end{array}$ \\
\hline Mother alive & $\begin{array}{l}-0.250 \\
(0.236)\end{array}$ & $\begin{array}{l}-0.284 \\
(0.237)\end{array}$ & $\begin{array}{l}-0.350 \\
(0.245)\end{array}$ \\
\hline Ideology/Political & [0.002] & [0.001] & [0.023] \\
\hline Liberal & $\begin{array}{c}1.064^{\star \star \star} \\
(0.295)\end{array}$ & $\begin{array}{c}1.069^{\star \star \star} \\
(0.294)\end{array}$ & $\begin{array}{l}0.766^{\star *} \\
(0.313)\end{array}$ \\
\hline Conservative & $\begin{array}{c}0.143 \\
(0.187)\end{array}$ & $\begin{array}{c}0.152 \\
(0.186)\end{array}$ & $\begin{array}{l}-0.127 \\
(0.209)\end{array}$ \\
\hline No thought & $\begin{array}{c}0.312 \\
(0.204) \\
\end{array}$ & $\begin{array}{l}0.360^{\star} \\
(0.206)\end{array}$ & $\begin{array}{l}-0.182 \\
(0.239) \\
\end{array}$ \\
\hline Other & $\begin{array}{l}1.068^{\star \star} \\
(0.544)\end{array}$ & $\begin{array}{l}1.069^{\star *} \\
(0.542)\end{array}$ & $\begin{array}{c}0.640 \\
(0.564)\end{array}$ \\
\hline Voted & $\begin{array}{l}0.374^{\star \star} \\
(0.185)\end{array}$ & $\begin{array}{l}0.432^{\star \star} \\
(0.187)\end{array}$ & $\begin{array}{c}0.192 \\
(0.210) \\
\end{array}$ \\
\hline Knowledge & -- & [0.559] & {$[0.587]$} \\
\hline K score & $\begin{array}{l}-- \\
---\end{array}$ & $\begin{array}{c}0.003 \\
(0.005)\end{array}$ & $\begin{array}{c}0.005 \\
(0.005)\end{array}$ \\
\hline $\begin{array}{l}\text { Believes partly } \\
\text { covered already }\end{array}$ & --- & $\begin{array}{l}-- \\
---\end{array}$ & $\begin{array}{c}0.079 \\
(0.199)\end{array}$ \\
\hline Demographics & {$[0.002]$} & [0.001] & [0.001] \\
\hline Years of education & $\begin{array}{c}-0.095^{\star \star \star *} \\
(0.034)\end{array}$ & $\begin{array}{c}-0.099 * \star * \\
(0.035)\end{array}$ & $\begin{array}{c}-0.140^{\star \star \star} \\
(0.038)\end{array}$ \\
\hline Female & $\begin{array}{c}0.197 \\
(0.153)\end{array}$ & $\begin{array}{c}0.236 \\
(0.155)\end{array}$ & $\begin{array}{c}0.086 \\
(0.170) \\
\end{array}$ \\
\hline Black & $\begin{array}{c}-0.589 \star \star \\
(0.231)\end{array}$ & $\begin{array}{c}-0.594^{\star \star} \\
(0.232)\end{array}$ & $\begin{array}{l}-0.506 \\
(0.261)\end{array}$ \\
\hline Other race & $\begin{array}{l}-0.012 \\
(0.295)\end{array}$ & $\begin{array}{l}-0.138 \\
(0.304)\end{array}$ & $\begin{array}{l}-0.260 \\
(0.326)\end{array}$ \\
\hline Hispanic & $\begin{array}{l}-0.100 \\
(0.293)\end{array}$ & $\begin{array}{l}-0.027 \\
(0.301)\end{array}$ & $\begin{array}{l}-0.209 \\
(0.322)\end{array}$ \\
\hline Student/Other & $\begin{array}{l}1.056^{\star \star \star} \\
(0.386)\end{array}$ & $\begin{array}{c}1.040^{\star \star \star} \\
(0.383)\end{array}$ & $\begin{array}{l}1.131^{* *} \\
(0.517)\end{array}$ \\
\hline Unemployed & $\begin{array}{l}-0.130 \\
(0.317)\end{array}$ & $\begin{array}{l}-0.156 \\
(0.317)\end{array}$ & $\begin{array}{l}-0.326 \\
(0.336)\end{array}$ \\
\hline Retired & $\begin{array}{c}0.009 \\
(0.257)\end{array}$ & $\begin{array}{c}0.050 \\
(0.260)\end{array}$ & $\begin{array}{c}0.434 \\
(0.286)\end{array}$ \\
\hline Homemaker & $\begin{array}{l}-0.015 \\
(0.342)\end{array}$ & $\begin{array}{l}-0.028 \\
(0.340)\end{array}$ & $\begin{array}{c}0.270 \\
(0.377)\end{array}$ \\
\hline Married & $\begin{array}{l}0.440^{\star *} \\
(0.221)\end{array}$ & $\begin{array}{l}0.398^{\star} \\
(0.220)\end{array}$ & $\begin{array}{c}0.213 \\
(0.243)\end{array}$ \\
\hline $\begin{array}{l}\text { Number of observatio } \\
\text { Pseudo- } R^{2}\end{array}$ & $\begin{array}{c}629 \\
0.128\end{array}$ & $\begin{array}{c}626 \\
0.133\end{array}$ & $\begin{array}{c}567 \\
0.139\end{array}$ \\
\hline
\end{tabular}

Notes: Sample is restricted to those who believe that Medicare did not already cover prescription drugs outside of the hospital for Medicare patients.

Equations also control for order of questions, cohabitation, widowhood, and divorced or separated. See notes to Table 11. 